\title{
الإدارة بالحب كمدخل لتنمية قيم المواطنة لدي \\ طلاب التعليم الجامعي
}

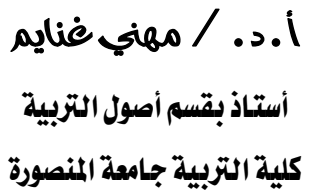

\author{
د. / مشيرة ابراهيم صابر \\ مدرس بقسم العلوم التربوية والنفسية \\ كلية التربية النوعية جامعة الزقازيق
}

يهذف البحث الحالي إلي التعرف علي الآسس النظرية لــإدارة بالحـب فــي الفكـر الإداري

الدعاصر، والنعرف علي الآسس النظرية للمواطنة وقيها ، وواقع إدارة الحب في تتمبية قيم الدواطنة لدي

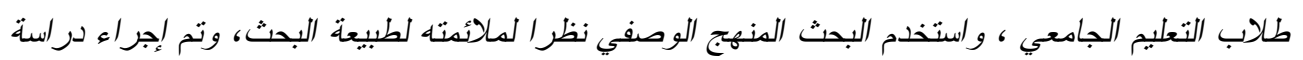

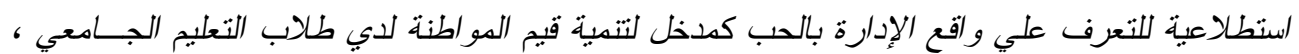

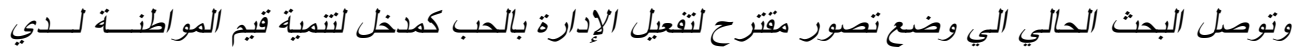

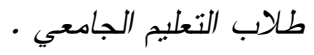

\section{Abstract}

The research aims to identify the theoretical foundation of management with love in contemporary management thought and to identify the theoretical foundations of citizenship and its values and the reality of management with love in developing citizenship values for university education students ، the research used the descriptive approach because its appropriate to the nature of the search and an exploratory study was conducted to identify the reality of management with love as an introduction to developing citizenship values for students of university education

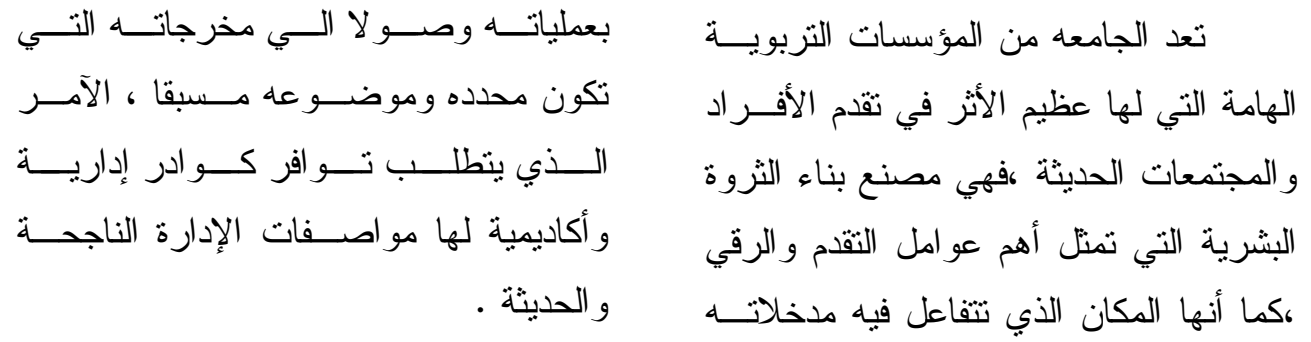


اساسا للاستقرار ،ولكن هذه القدرة ليـست مسئولية القيادة أو الجهاز الإداري وحـــده ، ولكنها مسئولية مشتركة تحفظها قوي الحب بالتعاون بين مختلــــ القيــادات الاداريـــة و الاكاديمية ولذلك تركز الإدارة بالحب علي دور العالمين ورفع مستوي مشناركتهم فــي التخطيط و التتفيذ و الرقابة و اتخاذ القــرار ات كوتركز علي البعد الإجتماعي والقيم التقافية للمؤسسات و أهميتها في صيانة رأس المــال الإجتماعي ،وتؤكد النظرية علي أنه لايمكن الحفاظ علي رأس المــال الاجتمــاعي دون الإرتقاء بالذكاء العاطفي للعاملين وتــدريبهم علي ادارة عو اطفهم وحثهم علــي التعبيـر عنها في أماكن العمل كواوضحت النظريـــة

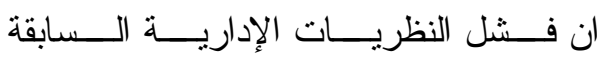
وتطبيقاتها لا يعــود الــي فـشل مناهجهــا وضعف مصداقيتها ولكنه بعود الي افتقـــار الإدارة للحب (سانفورد، ب، . . . r).

ومن هنا جاءت فكرة البحث الحــالي "الإدارة بالحب " وهو بمثنابة مــدخل جديـــ لتتمية قيم الإنتماء الوطني لدي طلاب التعليم الجامعي ، بيتحق الدر استة من وجهة نظـــر الباحثين ، ولم يتطرق اليه الكثير بالرغم من أنه لايقل اهمية عن الأساليب الحديثــة فــي كي

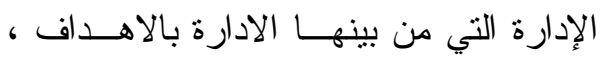
والإدارة المرئية ، و ادارة الجوده الــشاملة ، و الإدارة علي المكثنوف ، بل أنه يفوق هــذه
فمن المعـروف أن الجامعــة هـــي مؤسسة تربوية منكاملة تضم هياكل و أقــسام ووحـــدات إداريـــة ومــــوظفين و إداريــين ،و عاملون يعملون معا مــن أجــل تحقبــق

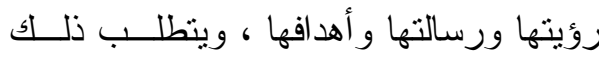
تو افر كو ادر إدارية و وموظفين علي درجــة

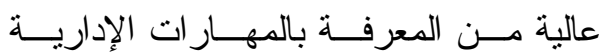
الناجحة في أداء أعمالهم ، و لآن الإدارة هي العامل الرئيس لنجاح اي مؤســسة ، وكلمـــا أحسن استغلال الموارد البــشرية و الماديــة

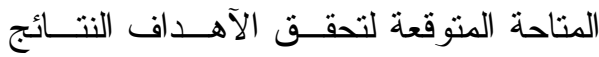

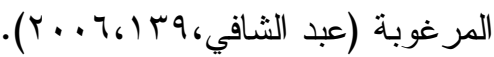
وبعتبر الجهاز الإداري هو المسسئول عند وضع رسالة المؤسسة الجامعية موضع التتفيذ من خلال رؤية و اضــــة ومبـــاديء ارشادية تتقح الأنظمة للحفاظ علي التــراث الثقافي وتطوير المهار ات التقنية ومهــار ات الإتـــصال و التفاعــل الانـــــاني (العبـــادي

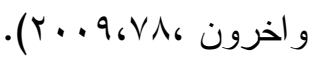

وفي ظل المتغير ات العالمية السياسية

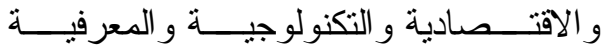
و المعلوماتية ،وتعدد دور ات التغيير أصبحت

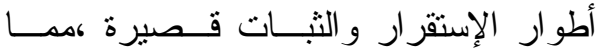
اضطر العالم الي العمل في بيئات مرنة حيث

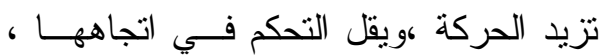

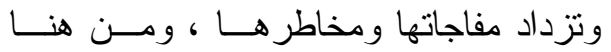
صارت قوة المنظمة علي التاقلم مع التغييـر 
العمل الجماعي و التعاون، وهذه القـيم تعــــ

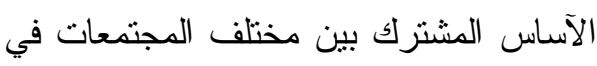

العالم أجمع ،وبالتالي تفعيل قيم المو اطنه من لالنين

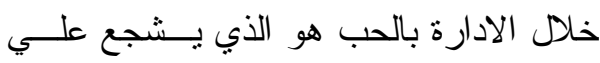

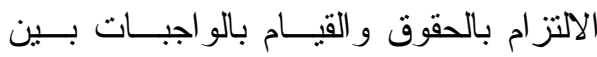

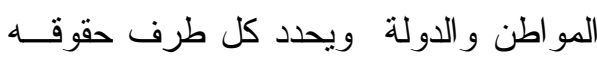

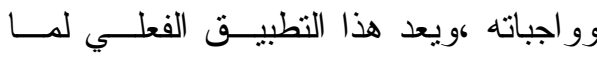

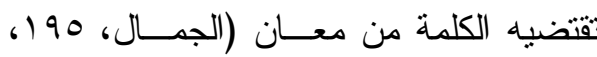

$$
\text { . ( r. . A }
$$

ولذلك تعد قيم المو اطنه من اهم سبل

مو اجهة تحديات القرن الحسـادي و العـشرين

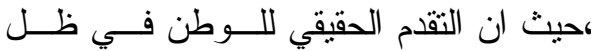

تحديات القرن الجديد ومسستجداته تــنـعه

عقول المواطنين ،فان اكسابهم قيم المواطنـــة

هو الركيزة الاساسية للمـشـاركة الايجابيــة

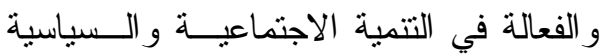

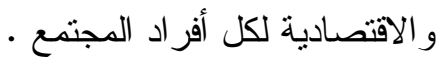

و الانتماء للوطن او المواطنه لايــاتي

بقرار سياسي او رغبة حاكم ،و انما ياتي من

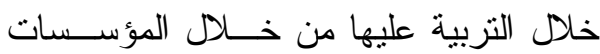

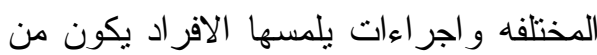
شأنها اشاعة الحق و العدالة و المساو اة بحيث يشعر الفرد بالر احة و السكينة و الآمان داخل ولفاول

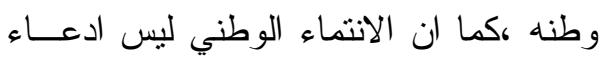
يدعيه الانسان أو مجرد كلمة نقال وانما هو

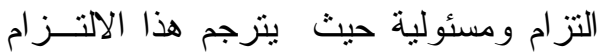

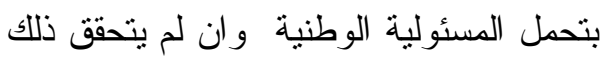

الآساليب حيث يعتبر اســاس قيــام هــذه

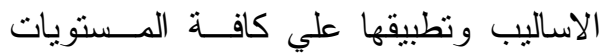

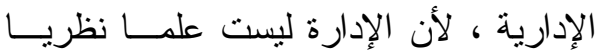

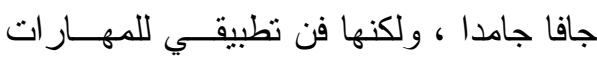
و القدرات التي يمنلكها الإداري فــي نجـــاح مؤسسته .

و هذا مايتم من خلاله الإنتقال بالإدارة من التاثير الروتيني إلي التأثثر السحري فــي الإني نفوس العاملين و الطـــلاب و أعــــاء هيأِـــة

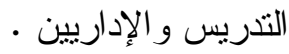

واتجهت العديد من الدول الي تطوير

التعليم وتحديثه عن طريــق ادارة نربويــة

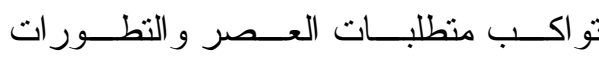

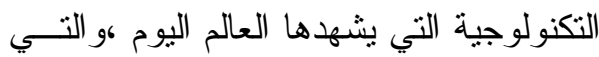

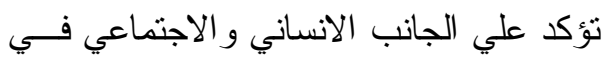
العملية الادارية ، ومدي مساهمة هذا الجانب في تحقيق اهدافها بالثكل المطلوب ،فاتجهت النظريات الإدارية المعاصرة في الإدارة الي بلي

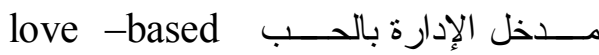
management الكاتبة كاتلين سانفورد ،و التــي تؤكسـد فــي كتابها علي قيمة الحب كأداه رئيسية لنجـائاح

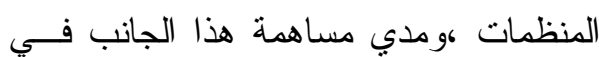
تحقيق اهداف المنظمات بالثكل المطلوب . وتعتمد المو اطنة علي مجمو عه مـن القيم الاصيلة المتمنلـــة فــي حـبـ الــوطن و الانتماء و الحرية و التو اد و المشاركة وحسـبـ 
و المفاهيم الثقافية و الــسياسية و الاجتماعيــة

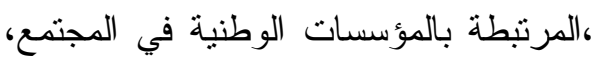

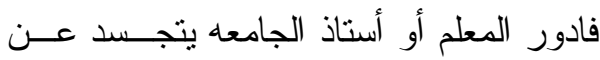
طريق القدوة الحسنه للطلبة ، فهو المربـي لني الذي تتمنل في شخصيته هذه القـيم ، فمــن

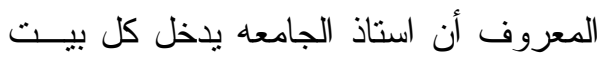

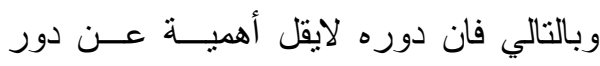
الإعلام في التوعية بمحاربة الفكر و النطرف ، و لاسيما كلما كان له علاقة ودية مع الطلبة بله بله ، ويحترم وينقبل ار ائهم ، كلما ساهم ذلك في وله ونس غرس القيم الوطنية لهم • وفي أبي مجال عمل نوجد بيئة ادارية

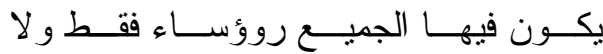
مر عوسين فقط ،و هذا يستدعي فـــمن يقــود رود فريق العمل أن تكون لديه مهار ات وقــدرات

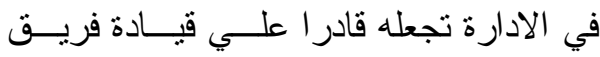

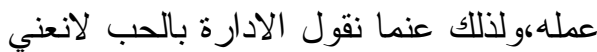
ذلـــك أن يجلــس الطالـــب مـــع الاســـاذ للتسامر ،ولكن نعني تقدير الجانب الانـساني

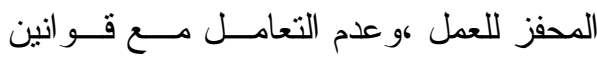
جامدة لا تتسم بالمرونه ،بل العمل معا بروح الفريق الواحد وتطبيق مبدأ التفويض للطلاب

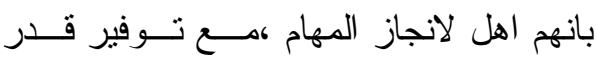

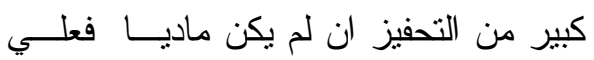

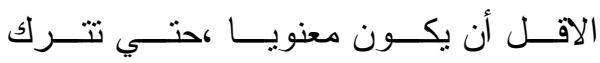
الكلمة اثز طيب في نفوس الطلاب (سانفورد

$$
\text { (r.... }
$$

أدي الي شعوره بعدم حبه للمكان الذي يوجد

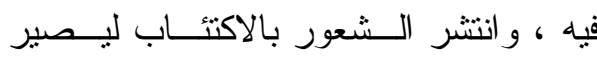
اكتئاب وطني وقد ذكر عكاشــة أن اســبابه

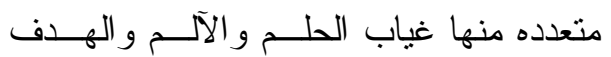
وخيبة تحقيقي التوقعات وتهميش المـــواطن

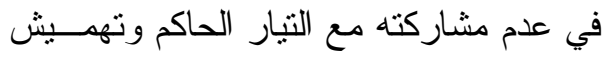
منطلباته و هذا تأثنيره و اضتح علـي الـشتعور الداخلي ممايؤثر في الحماس للعمل و الإنتاج

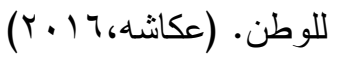
ويمكن تصور الهية الإدارة بالحسب

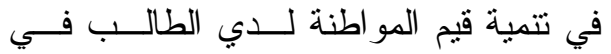
الإنتقال من الجمود و النمطية وكر اهية الآخر الي التــسامح و الثقــدير وتثويــة العلاقــات الاجتماعية ،كما انها نساعد الفرد في تقبــلـل معتقدات و افكار الاخرين في حالة اخــتلافهر

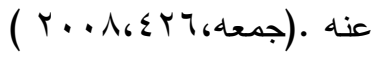
ومن هنا تبرز أهمية مؤسسات التعليم

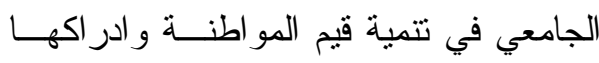
و اكتساب مفاهيمها وسلوكياتها ، وذللك مـنـ خلال آلية الإدارة بالحب التي تساعد الطلاب

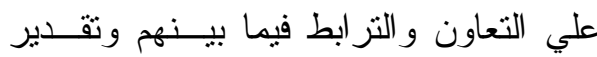

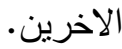

وتعتبر الجامعة هي المـسئولة عـن الدفاع عن الهوية الوطنية وترسيخ مبـاديء

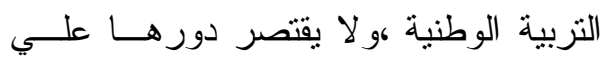
تتمية الإتجاهات الإيجابية الوطنية عند الطلبة

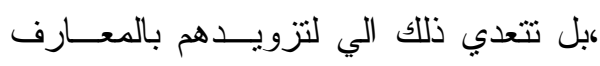




$$
\begin{aligned}
& \text { الجميع فــي إنتاجهــا ودعمهــا (الــصغير } \\
& \text { (r. . 960 \% } \\
& \text { فالمؤسسات بحاجـــة ماســـة لــلإدارة }
\end{aligned}
$$

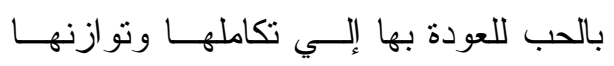

$$
\begin{aligned}
& \text { ومرونتها ، و إعادة تشكيل الموارد البـشرية } \\
& \text { ممن يعملون فيها، و هذا مانعنيه هنا هو بناء }
\end{aligned}
$$

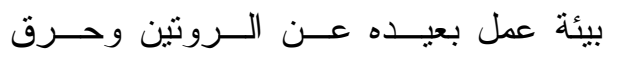

$$
\begin{aligned}
& \text { الاعصاب ، وقريبة من الفطرة التي فطرنــا }
\end{aligned}
$$

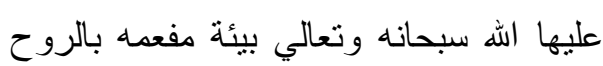

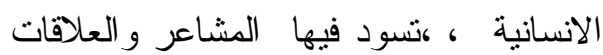

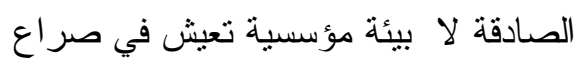

مشكلة البحث :

في ظل المتغير ات العالمية في شتي المجالات السياسية و الاقتصادية و التكنولوجية

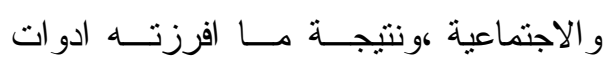

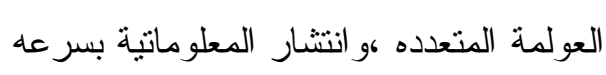
كبيرة حتي اصبحنا نعيش فيما نسميه في هذا العصر بالعصر الرقمي الذي يقوم بدور كبير

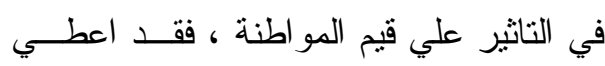
للشباب مساحة واسعه من التعبير عن الرأي لا يجدونها بين جدران المدارس او الجامعات

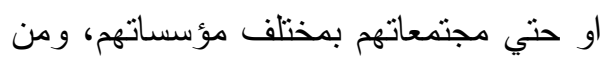

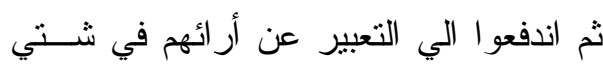

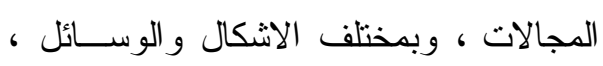
متجهين في ذلك الي اسقاط كافة التابوهــات ولتهات القديمة التي كانوا لايجر عون من قبل علـي لـي

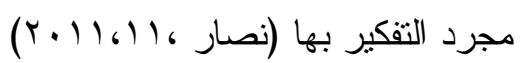

وتقوم الإدارة بالحب علــي الآركـــان

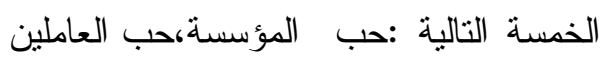

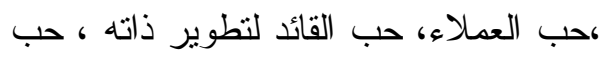

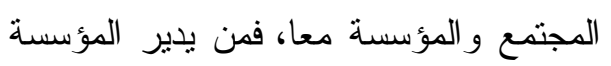
بالحب و الود يحرص علـي حــب العدــلاء

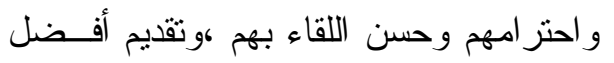
الخدمات بصدق وكفاءة وجودة عالية ،بعيدا

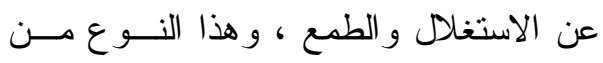
القياديين يحب مجتمعه ،وينتمي اليه ،ويؤدي هذا المدخل الإداري الجديد الي تطوير الذات

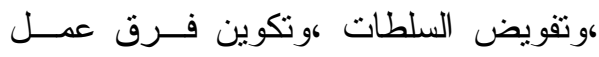

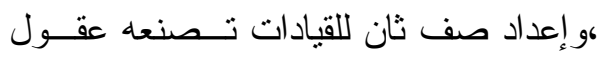

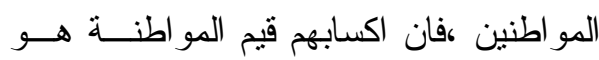
الركيزة الأساسية للمشاركة الإيجابية و الفعالة في التتمية الإجتماعية و السياسية و الإقتصادية لكل أفر اد المجتمع (سانفورد ، ،ب، . . . ץ) . وبالتالي فان تطبيــق مــــل الإدارة بالحب يتطلب أعـضـاء فــاعلين متعــاونين ولديهم الرغبة الحقيقية في التغيير ويملكــون بـاءون

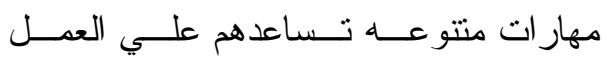

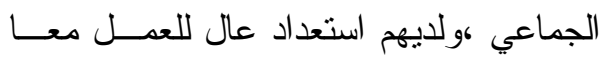
و التعلم ويتصفون بالمرونه التـي تـساعدهم

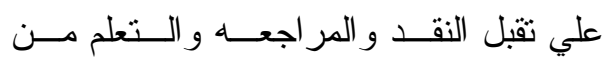
الاخرين وبالاضافه الي توفر القيــاده التــي ولئي

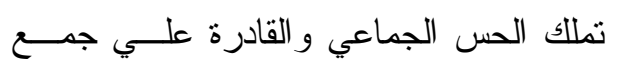
أعضاء المؤسسة خلف رؤية و اضحة يشترك 
تو اجه المواطنة وتؤثر في انتماء الــشباب ،

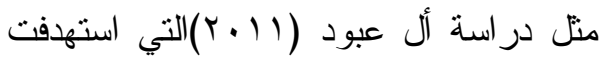

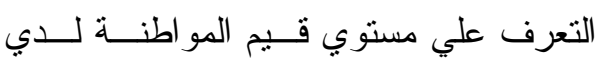

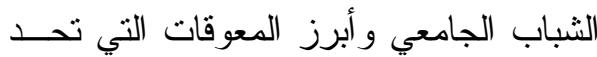

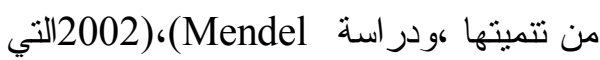
استهدفت التعرف علي الآنـشطة و البــــر امج التي تدعم قيم المواطنة لدي طلبة الجامعسه

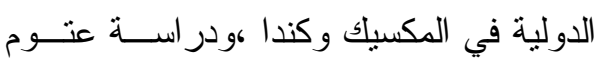

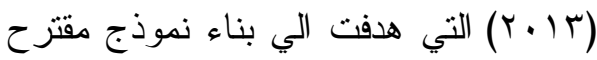

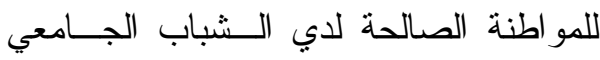
كودر اسة الصائغ (ع ا +r) التي هدفت وضع استر اتيجية مقترحة للجامعات السعودية فـي

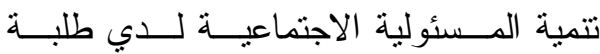

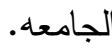
ومن خلال تجربة الباحثان في الميدان

التعليمي الجامعي ، قد لاحظو ا ضعف نو ازع

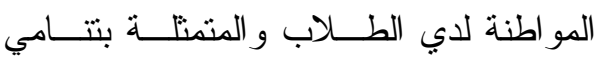

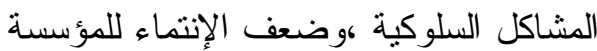

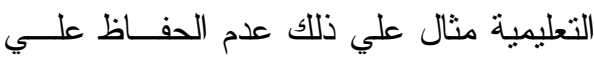

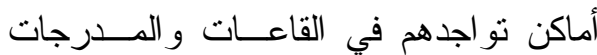

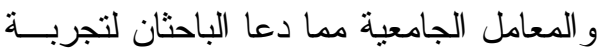
مدخل الإدارة بالحب في تتمية قيم المو اطنـــــ

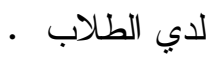
ويضاف الي ذلك أيضا مــن خــلال مر اجعة در اسات القيم في التعليم الجامعي في

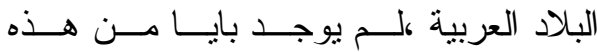
الدراسات بر امج محدة او مو اد تتعلق بتعليم
ونتيجة ما يجــري مــن صــر اعات

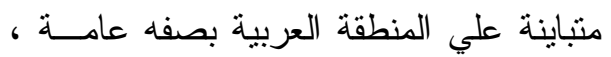

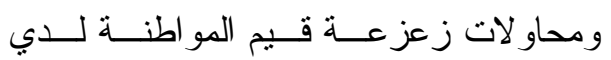

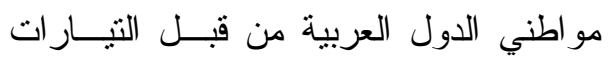
الغربية التي أفرزت وبلاشك سيطرتها علــي لـي الثقافات و الهويات القومية و المفاهيم التعليمية وخاصة بعد قيام العديد من الثثرات العربية (تونس ، مصر ، ليبيا ،سوريا ،اليمن ) وبناء علي دراسة استطلاعية أجر اها الباحثان في التعـرف عانـي مـــذل الإدارة بالحب كأسلوب في تتمية قيم المواطنة لــدي طلاب التعليم الجامعي ،طبقت علي عينـــة من طلاب كلية التربية النوعيـة وعـددهم

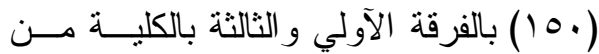
مختلف الثعب . أوضــــت الدر اســــة الإســـــلاعية ضعف قيم الإنتماء التي تقتقــر الــــي الإدارة بالحب لدي طلاب التعليم الجـامعي لآنهــ

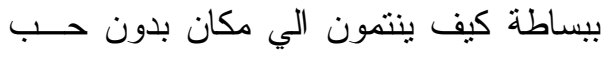
هذا المكان وحب من فيه ، و اتضح ذلك من

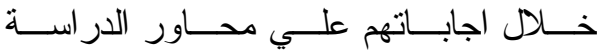
الاستطلاعية .(ملحق الفي نهاية البحث) وفي ضوء نتائج البحوث و الدراسات

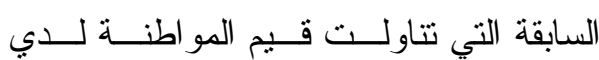
الثباب، و البر امج الموجهة لتتمية تللك القـيم

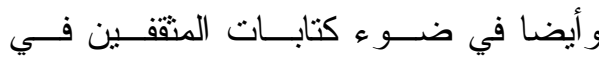
السنوات القليلة الماضية حول التهديدات التي 
r- مالآسس الفكرية و الفلسفية للمواطنه

$$
\text { وقيمها ؟ }
$$

r- ما و اقع الإدارة بالحب كمدخل لتتمية

قيم المواطنة لــدي طــلاب التعلــيم

$$
\text { الجامعي ؟ }
$$

ــ ــ ما الرؤية المستقبلية لتفعيـلـ مـــخل

الإدارة بالحب في تتمية قيم المواطنة

لدي طلاب الجامعات المصرية ؟

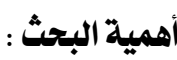

$$
\text { تتضح أهمية البحث الحالي في :- }
$$

* يركز علي موضـــوع الإدارة بالحــب

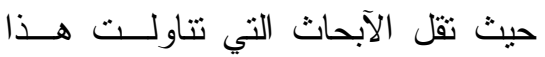

الموضوع في البيئة العربية بشكل عـام

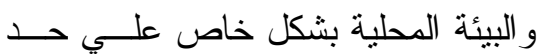

علم الباحثين ،لذلك يأتي هــذا البحــث

ليسهم في اثر اء هذا المجال من البحوث

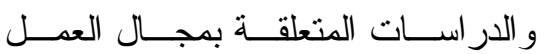

الاداري في المؤسسات التعليمية .

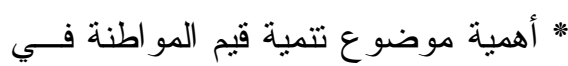

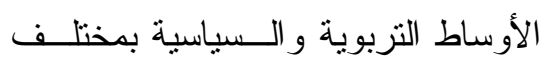

انحاء العالم ، و هذا انعكس بدوره مـن

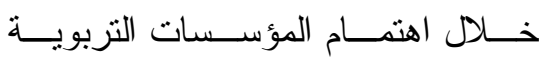

بالتربية الوطنية عبر تضمين المنــاهج

القيم الوطنية و انعكاس تللك القـيم علــي

سلوك الطلبة وهو مايؤكد دور الجامعه

في تتمية قيم المو اطنة لدي الطلاب .
وتتمية القيم وتقويمها وان كان يوجد فقليـلـل الي حد ما علي حد علم الباحثان ، وبــالر غم ونمان من تأكيد الباحثين في مجال التعليم الجـامعي لـاني

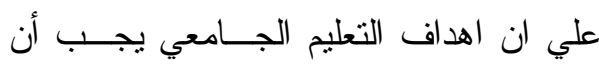

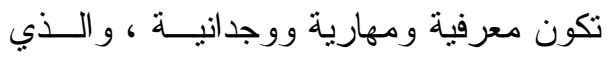
نادت به معايير الجوده في ضرورة نوفرهن وتحقيقها في توصيف المقررات الدراســية ، فقد أصبحت المجال الآكثر شيوعا في التعليم الجامعي و العالي هو اكتـساب المعلومسـات

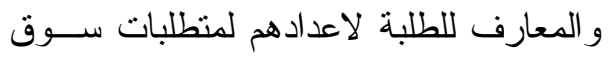

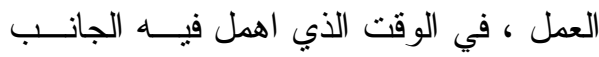

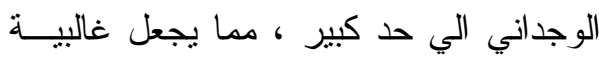

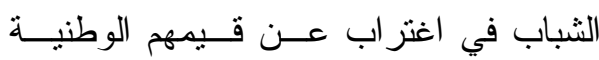

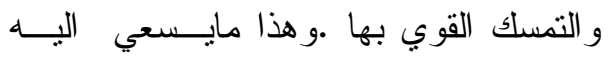
البحث الحالي فــي تــدعيم هـــا الجانـبـ الوجداني وتأسيسا علي ما سبق يمكن صــياغة مشكلة البحث الحالي في الــسؤال الــــئيس

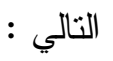
كيف يمكن تفعيل مدخل الإدارة بالحب فــي تنمية قيم المواطنة لــدي طــلاب التعلـيم الجامعي ؟ - إبه ويتفرع من هذا السؤال الاســئلة الفرعيـة التالية : 1 - مالآسس النظرية لـــلإدارة بالحــب ،

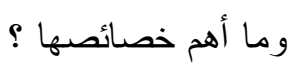




\section{مصطلحات البحث :}

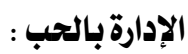

تعددت تعريفات الإدارة بالحب ومنها تعرف

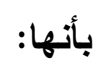

مدخل جديد من مداخل إدارة التغييــر

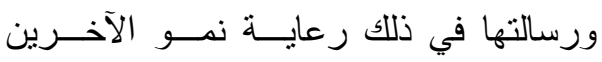

لمو اجهة منطلبات التغيير بالمقاومة و الإستياء

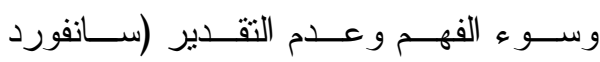

(r.... . V。

وتعرف أيضا بأنها التنأثير الـسحري

في العاملين، مما يحقــق فــرص الإبــــاع

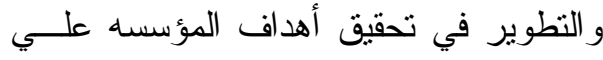
الوجه الاكمل ، وهذا يتوقف علي قدرة القائد التزبوي في رعاية وتوجيه العاملين ، وتقديم

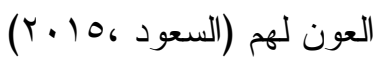

وقد ذكر عن الإدارة بالحـب "اعــادة

تصميم بيئة العمل ،لتقام علي اسس جديــــه من التعاون و المشاركة بين زملاء العمل في لهي اطار من الحب و التفاؤل و السعادة الانتاجية بــين الــرئيس و المـــر عوس وتتميــة روح

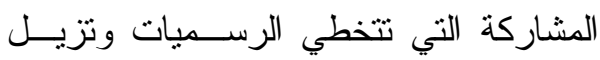

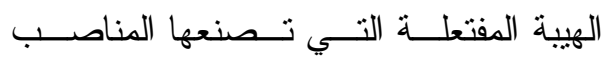

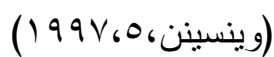
وتعرف الإدارة بالعب اجرائيا بأنها: الآسلوب او الكيفية او الطريقه التي يدار بها

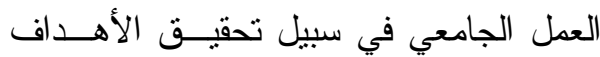
المنشودة للجامعة مر اعاة للجو انب الوجدانية
* أهية المرحلة العمرية التي بتوجه اليها

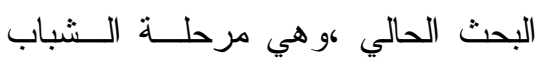

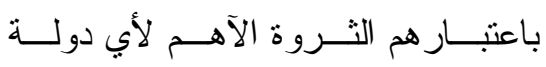

و المحور الأساسي في احداث التمية .

* التوصل الي تصور مقترح لتميــة قــيم

الإنتماء الوطني في ضوء مدخل الإدارة

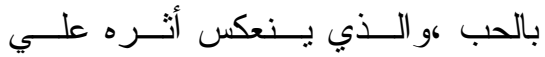

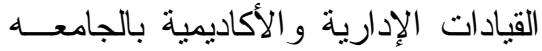

كمن خلال و عيهم بثقافة الإدارة بالحـبـ

كمن خلال زيــادة معسـارفهم ،وتتميــة

قدر اتهم علي حل مشكلاتهم بل وتجنبها

قبل وقوعها وبالثالي تطــــير كليــاتهم

و وجامعاتهم

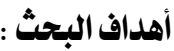

تتمثل اهداف البحث الحالي في :

* التعرف علي الاسس النظرية لــلإدارة بالحب في الفكر الإداري المعاصر

* التاصيل النظري لمفهوم المواطنه وقيم

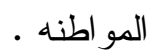

* التعرف علي واقــع إدارة الحـبـ فــي تتمية قيم المو اطنة لدي طلاب التعلــيم الجامعي * تقديم مجموعه من المقترحسـات التــي تسهم في تتمية قيم المو اطنة لاي طلاب من فلري التعليم الجامعي في ضوء لئ لدخل فئ الادارة بالحب 


$$
\text { و العلاقات الانسانية في التعامـلـ مــع كـل قيم المواطنة : }
$$

تعددت تعريفاتها ومنها :أنها مجموعة

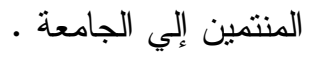

من الموجهات السلوكية المؤثرة في شخصية (القيم :

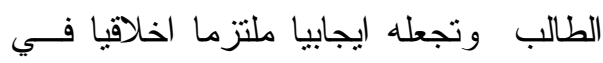

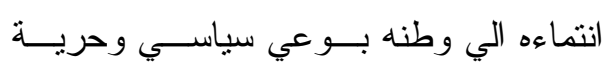

تعرف القيم بأنهــا: مجموعـــه مــن

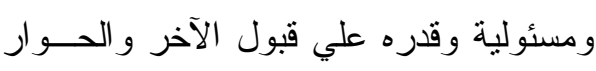

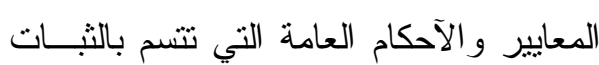

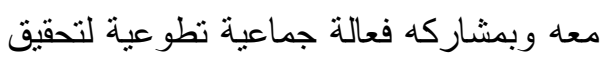

و الإستقرار وتتفق مــع الآسـس العقائديــة

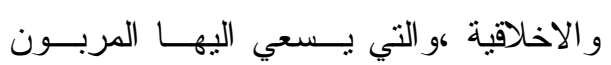

الآمن الداخلي والسلام الاجتماعي و العدالـــة

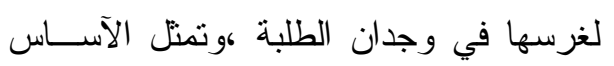

و المساو اه و الاحكام التي يصدر ها الفرد عـنـ

و المبدا الذي يجب ان يلتزم به الجميع لتحقيق

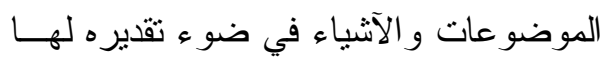

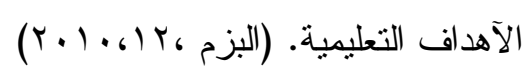

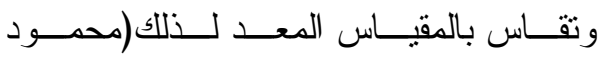

$$
\text { (r...9.0VV。 }
$$

وتعرف ايضا بأنها المفردات التـي

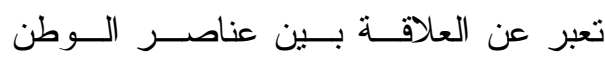

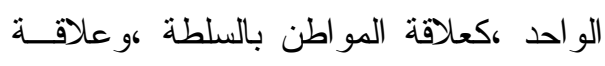

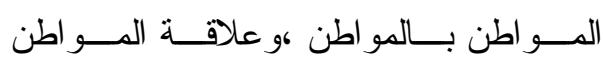

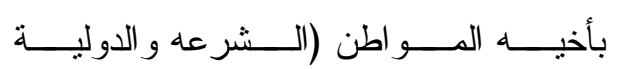

$$
\cdot(r \cdot 1) \text {, rON، }
$$

\section{وتعرف قيم المواطنه اجرائيا بأنهـــا}

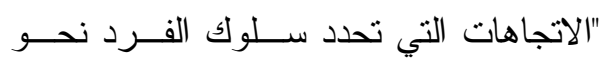

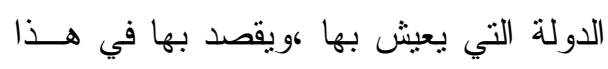

البحث الانتماء للوطن -التسامح - المسئولية

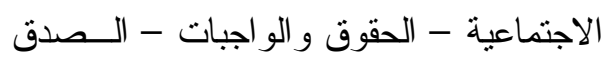

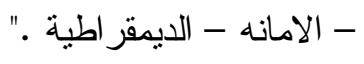

وتعرف القيم اجرائيا بأنها : مجموعة

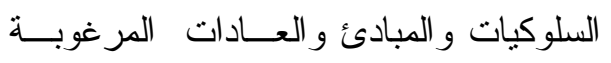

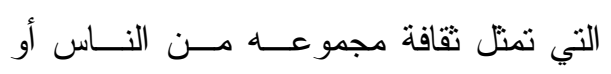

$$
\text { جماعه او فرد . }
$$

المواطنة :

الوطن في اللغة : هو مكـــان أقامــة

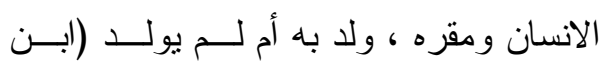

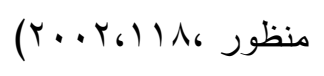

التفاعـلـ الإيجــابي بــين المـــواطن

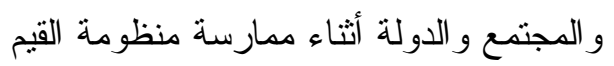

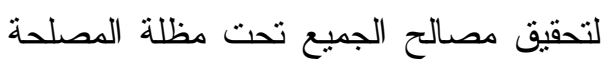

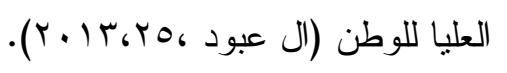

\section{وتعرف المواطنـــة اجرائيــا بأنهــــا}

:الأسس و المبادئ التي تحدد علاقة طـــلاب

التعليم الجامعي بوطنهم وتوجهرم نحو بنــاء الوطن وتعميق شعور الو لاء و الانتماء له له 
كبيرة ، كما اظهرت النتائج وجود فروق دالة

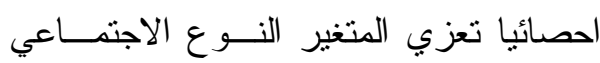

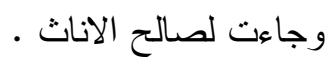

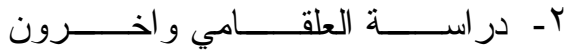

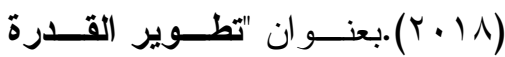

المؤسسية الثانوية علي ضوء مدخل

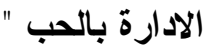

هدفت الار اسة الي التعـرف علــي

الاطر النظرية للقدرة المؤسسية بالمؤسسات

التعليمية و الوقوف علي الآسس النظرية فــي لإني

الادارة بالحب ، و استخدمت الدراسة المنهج

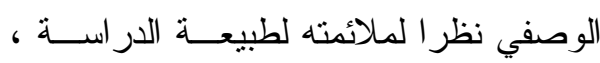

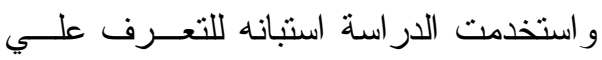

و اقع ممارسة ادارة المدرسة الثانوية العامة

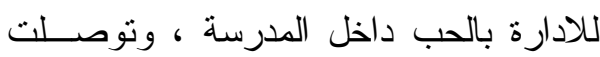

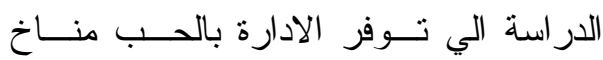
مؤسسي محب للعــاملين يزيــــــــــــائهر و انتمائهم المدرسي ،ورفع كفاءتهم الانتاجية وتهتم برأس المال البشري باعتبارهم الثزوة

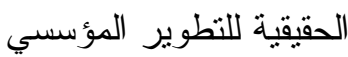
ثانيا : دراسات متعلقة بقيم المواطنة أ- دراسات العربية 1 - در اسة الغلبان (19 (Y) بعنوان"فاعلية برنامج كمبيوتر متعدد الوسائط فــي لـي تنمية القيم الوطنية لاي عينه مـن

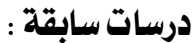

يوجد عدد من الدرسات السابقه سوف يــتم تناولها علي النحو التالي : اولآ :دراسات متعلقة بالإدارة بالحب

$$
\text { أ- دراسات عربية : }
$$

ا - دراسة المــزاودة و الــداود (1)

بعنوان "درجــة ممارســـة القيــادات المدرسية في مدارس لواء الباديــة الثمالية المعلمين والمعلمات الغربية في محافظة المفرق لمباديء القيادة بالحب من وجهــة نظــر المعلمـين

\section{و المعلمات}

هدفت الدراسة الي التعـرف علـي

درجة ممارسة القيادات المدرسية في مدارس لئس

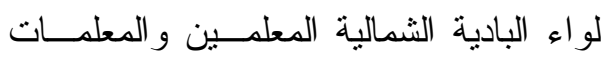
الغربية في محافظة المفرق لمباديء القيــادة بالحب من وجهة نظر المعلمين و المعلمــات

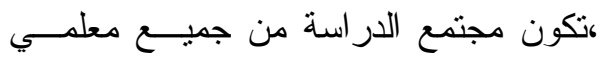

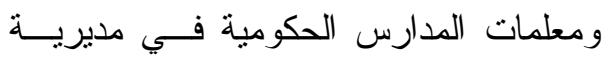
تربية وتعليم لو اء البادية الشمالية الغربية في

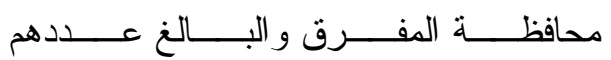

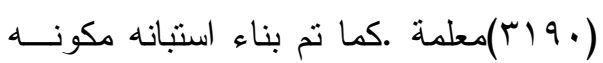
من (q)فقره موزعه الي اربــع مجــالات

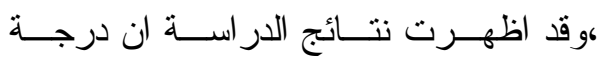
ممارسة المدرسية في مدارس لواء الباديــة

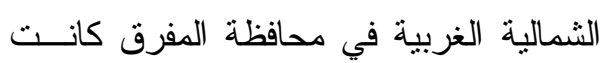


الثانوية ،وتقديم مجمو عه من المقترحات التي

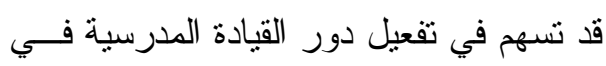

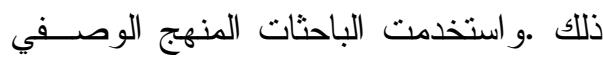

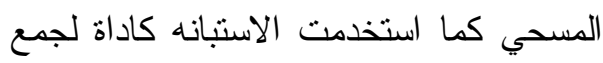

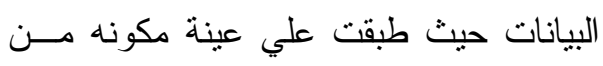

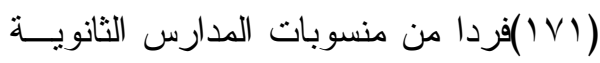
وتوصلت الدر اسة الي مجموعه من النتائج

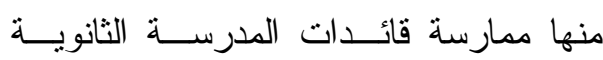
لدورهن في تعزيز الآمــن الفكـــي لــدي

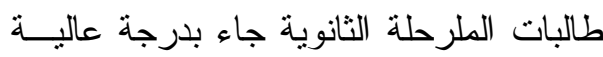

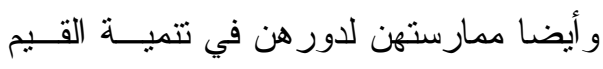

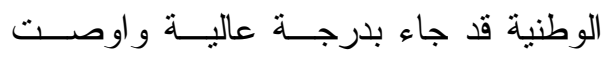

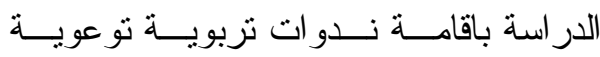

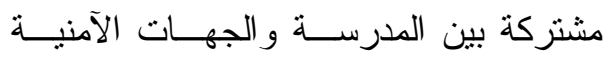
وتعميق مفهوم الامن الفكري فــي أنــشطة

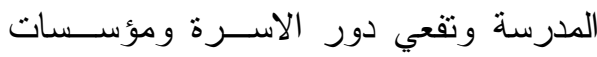

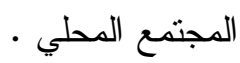

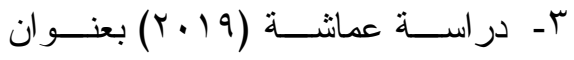

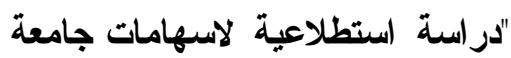
الطائف في تنمية قيم المواطنة لاي الطالبات واثر هذه القيم في مستوي طموحهن الآكاديمي واتره هدفت الدر اسة التعرف علي أهم قـيم

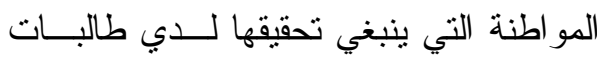
جامعة الطائف و التعـرف علـي مسـتوي لإني

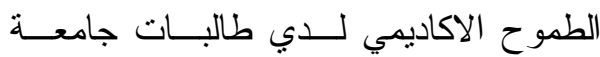
الطائف ،وفهم طبيعة العلاقة بــين متغيــري
الطالبات المعاقات فكريــا القـــابلات للتعلم هدف هذه الدراسة الــي التعـرف علي مدي فاعلية برنامج كمبيوتزي متعـدد الوسائط في تتمية القيم الوطنية لدي عينه من

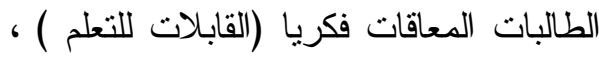
واستخدم البحث المــنهج الوصــفي نظـــرا لملائمته لطبيعة الدر اســـة، وتــــ اســتخدام مجو عتين ضابطة وتجريبية للتعـرف عافي مدي فاعلية البرنـــامج حيــث تــم تحقيـق التجانس بين افراد العينة و استغرق تطبيــق

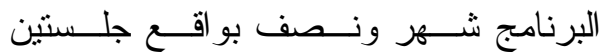

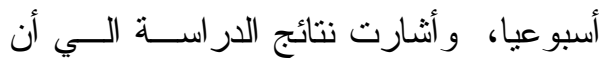

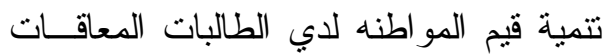

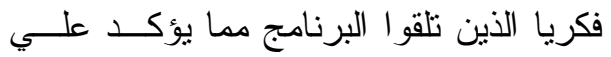
فاعلية البرنامج الكمبيوتري متعدد الوســائط

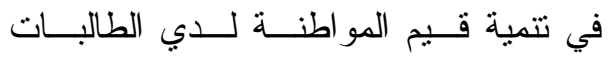
المعاقات فكريا ، وتم تفسير النتائج في ضوء الاطار النظري و الدر اسات السابقه .

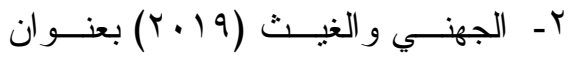

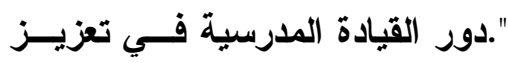
الآمن الفكري وتنمية قيم المواطنــة لاي طالبات المرحلة الثانوية بالمدينة

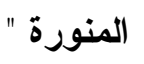

هدفت الدر اسة الي التعرف علي دور

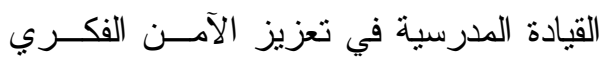

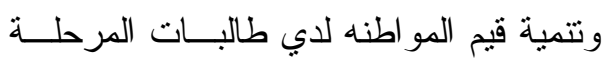


الدراسية في كافة مكاتب التعليم بمنطقة حائل كوبينت النتائج دور معلم المرحلة الثانوية في تتمية قيم المو اطنة لدي الطلاب كانت عاليـــة

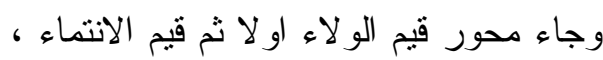

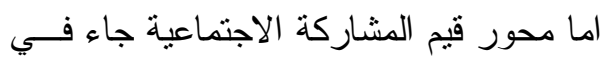

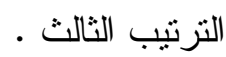

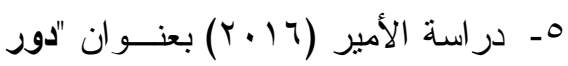
المدرسة في تنمية قيم المواطنة لاي

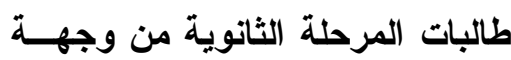
نظر المعلمات في المملكة العربيــة

$$
\text { السعودية . "نظر لمعات }
$$

هدفت الدر اسة إلي الكثف عـن دور

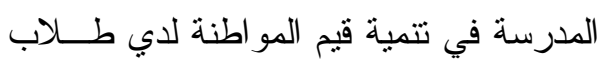

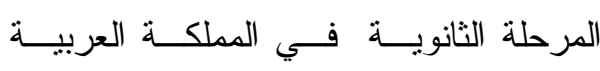
السعودية من وجهة نظر المعلمات ،ولتحقيق هدف الدراسة تم بناء أداة تكونت بـصني وصورتها النهائية من (•r) فقرة تقيس مدي مـسـاهمة المدرسة في تتمية قيم المواطنة لدي الطالبات

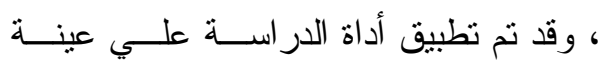
مكونه من (9.9 (19) معلمة من معلمات المو اد لماد

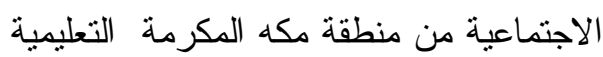
كتم اختيار هابالطريقة العشو ائية ، وقد دلــت

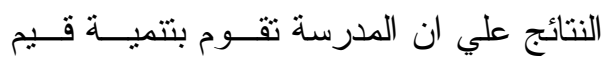

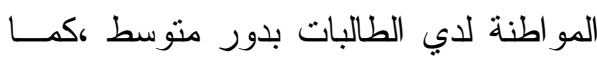
تبين عدم وجود فروق ذات دلالة احـصائية

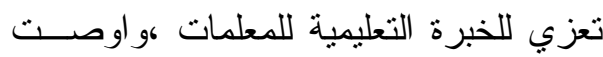
الدراسة بتعزيز دور المدرسة في تتمية القيم
الدراسة الحالية: قــيم المو اطنــهـه ومـسـتوي

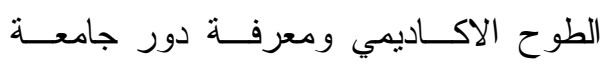

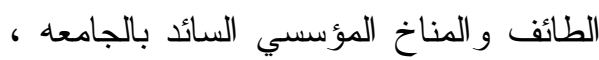
و المقرر ات الدر اســـية وكفـــاءة أعــــاهيئة التدريس ،و الآنشطة الطلابية في تتمية قـيم

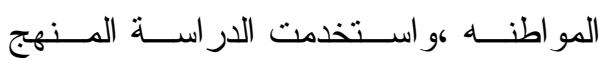
الوصــفي وعينــة الدر اســـة الاســنطلاعية

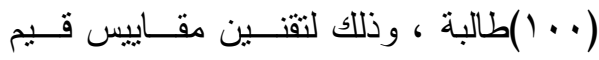

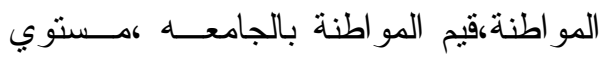

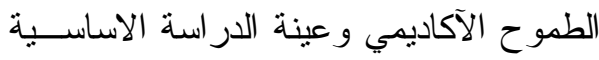
(r...) الطائف ،وجاءت النتائج لتوضـيح ان قـيم المو اطنه تتبيء بمستوي الطموح الاكــاديمي

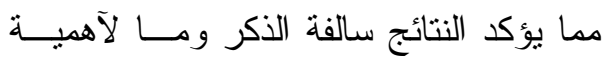

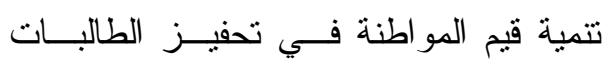

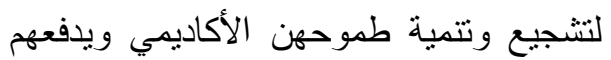

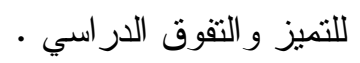

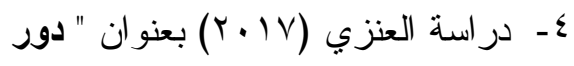
معلم المرحلة الثانوية في تعزيز قيم المواطنة لدي الطلاب من وجهة نظر

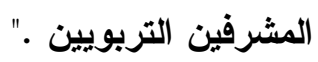

هدفت الدر اسة إلي التعرف علي دور معلم المرحلة الثانوية في تعزيز قيم المواطنة

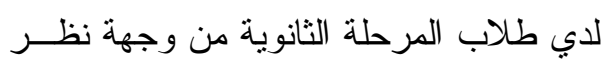
المشرفين التربويين ،ولتحقيق هدف الدراسة

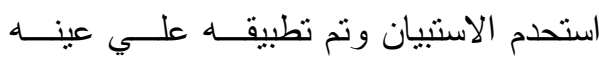

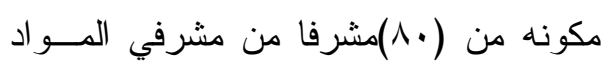




\section{ثانيا : الدراسات الأجنبية}

l بعنو ان " طريقة ادرالك وممارسة قيم المواطنة لــــي طــلاب المــرحلتين الثانوية و المتوسطة "لموية

هدفت هذه الدر اسة التعــرف عاتـي طريقة ادر الك وممارسة قيم المو اطنـــة لــدي طلاب المرحلنين الثانوية والمتوسطة ،الذين

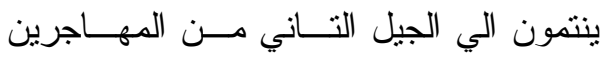
للو لايات المتحدة الآمريكية وكثشفت نتــائج

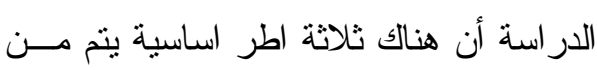
خلالها ادر الك تلك القيم وهي اطلار الاســرة و المجتمع المحيط الذي له الاثر الاكبر فـي

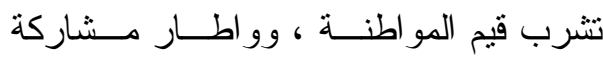

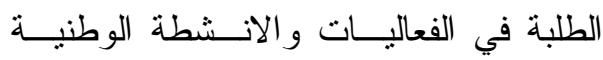
كواطار تعزيز وضعهم القانوني من خــلهل

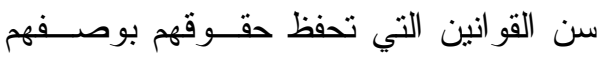

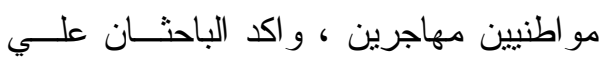

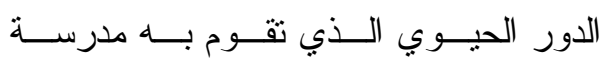

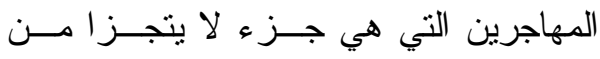
المجتمع المحيط في تعميق قيم المواطنة لدي لهي

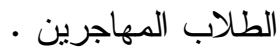

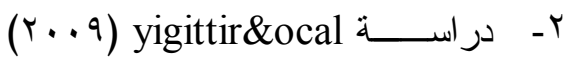
بعنوان " الميول القيمية لدي طــلاب المرحلة السادسة في تركيا هدفت الدراسة الي تعرف الميــول

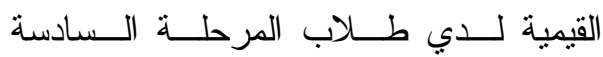

الوطنية لدي الطالبات ،و التي أظهرت ضعفا

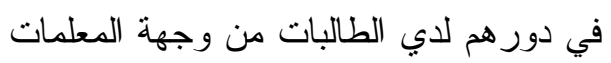

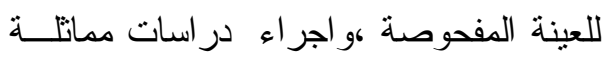
في مناطق تعليمية اخري في المملكة العربية

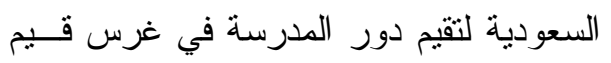

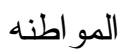

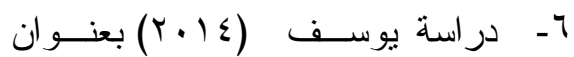
"تنمية قيم المواطنة لطلاب التعلـيم بـونيم الثاتوي العام في ضـــوء التحـــولات

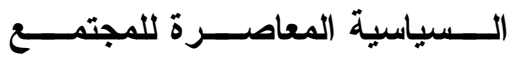

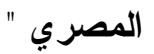
هدفت الدر اسة التعرف الــي مفهـــوم المو اطنه وقيم المو اطنة في مرحلـــة التعلــيم الثانوي ، وابراز دور المو اطنه للطلاب من

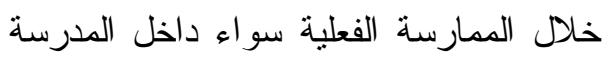

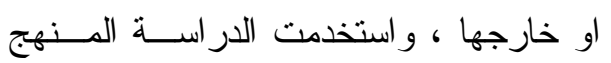

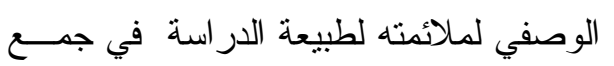
الحقــائق و المعلومـــات المتعلقــــة بظـــــاهرة المو اطنه ،كما استخدمت الدر اســة اســنبانه

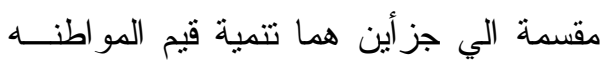

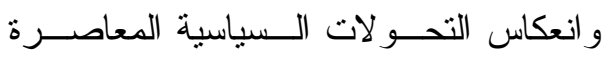

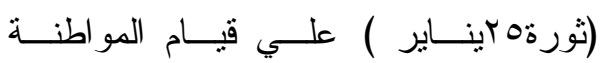
كوتوصلت الدراسة الي وضع تصور مقترح

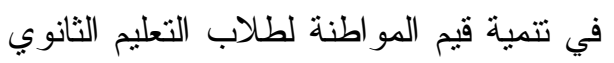
في مصر في لمر 


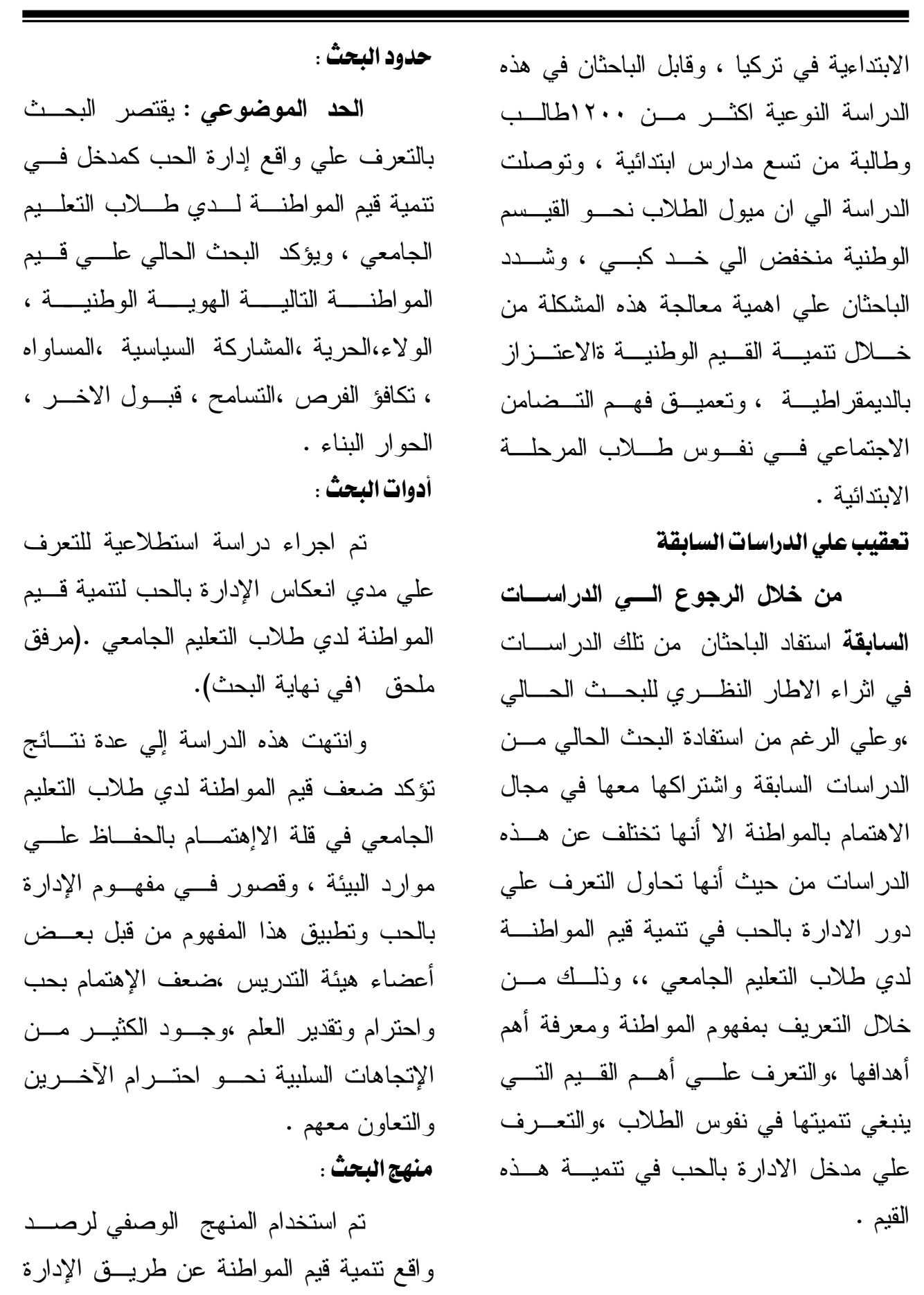


الإنسان مشاعره و عو اطفه في عمله ،ومسنـ

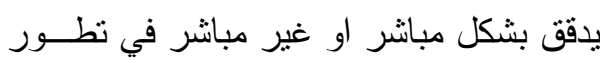

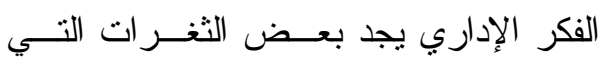

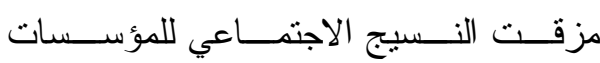

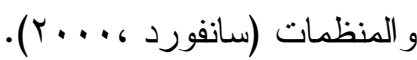

ومن هنا تعرف الإدارة بالحب بأنها: توفير المناخ الذي يشعر الموظف فيه بانـــه

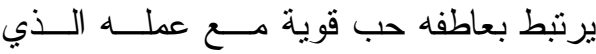

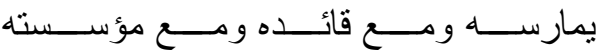

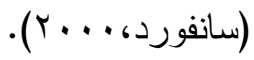

وتعرف أيضا بانها حـرص الإدارة علي وضع الموظف المناسب فــي المكــان المناسب ، مع تأدية الموظف للعمــل الــــي

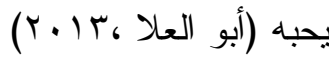
مرتكزات الإدارة بالحب .

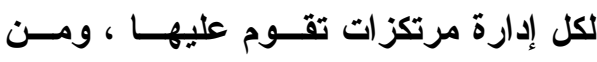

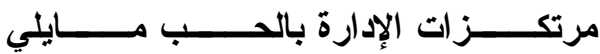

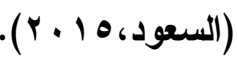
• الإدارة بالحب و الإدارة بالفطرة وجهــان

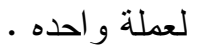

• قيادة المؤسسات بفطرة الامومة .

• تركز القياده بالحب علي دور العساملين ورفع مستوي مشاركتهم في التخطــيط و التنفيذ و الرقابة و اتخاذ القر ار ات .
بالحب لدي طلاب التعلــيم الجـامعي فـي

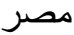
أولآ: الإطار النطري للإدارة بالحب . managed by . مفهوم الإدارة بالحـبـ love

تعتبر كاتلين سانفورد اول من تنبـــت

مفهوم الإدارة بالحب ،حيث قامــت بتــاليف كتابها"الادارة بالحب : كيف تفوز المنظمات بالحنان و القياده و الفطرة " ، وتعتقد كـانلين في كتابهــا ان فـشنل النظريــات التربويــة وتطبيقاتها لا يعود الي فثل مناهجها اة الــي لـي أخطاء فيها بل يعــود الـــي افتقــار الإدارة بالحب أو القيادة بالحــب ،و افتقـــار القيــادة

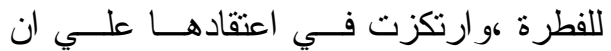
الحب هو سحر الامومه ،والإدارة بفطـــرة الامومه تخضع لنفس السحر ،فالحـبـ هــــ

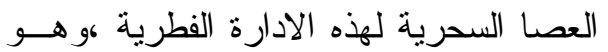
المسئول عن نجاح المنظمات وتميزها . وتتبع فلسفة الإدارة بالحب من مبــــأ أهمية دور الإدارة في صــيانة رأس المــال البشري الاجتماعي ،بحيث لا يمكن المحافظة

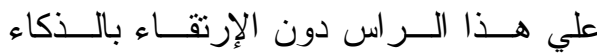
العاطفي للعـاملين ،وتــــينهم علــي إدارة عو اطفهم وحثهم علي التعبير عنها في أماكن العمل ،فمن المـستحيل أن يتــرك الانــسان منظومة عو اطفه في منزله قبل الذهاب الـــي عمله كل صباح .كما أنه لا يعقل ان يعطل فئل 


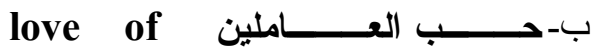

employees

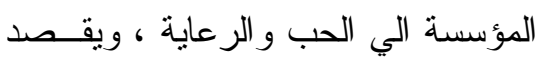

بها مساعدتهم في الكثف عن مهار اتهم

ومو اهبهم وتمكينهم من اطلاق طاقــاتهم

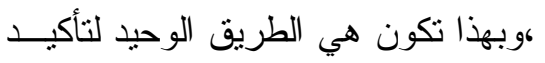

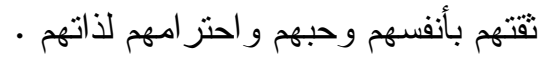

ت-حب العملاء love of clients :حـب

العميل وخدمته بصدق من أهم ركــائز

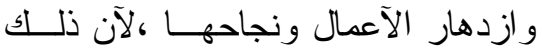

يترجم الي كفاءة الآداء وأدب في اللقــاء

من ناحية اذا أحبينا من نقـوم بخدمتـــه

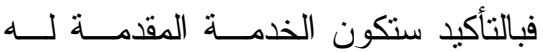

ممتازة ،و اننا جميعا عملاء لخدمة معينة

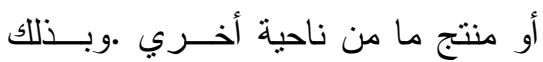

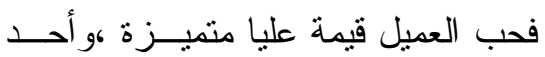

عناصر الضمير المؤسسي ،ومبدأ تؤكد

عليه الفطرة .

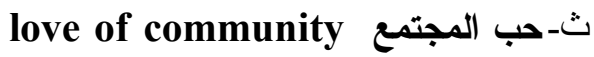

/society : من المعروف أنه لا تتفصل

أي مؤسسة عن المجتمع الذي توجد فيه

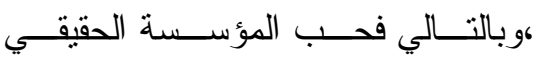

للمجتمع هو أقصر الطرق لتحقيق ،ومن

هذا النجاح يؤدي بالمؤسسة للمزيد مــن

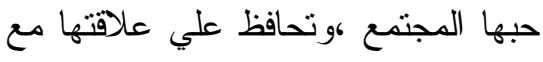

المجتمع ،و الادارة بالحب تعتبر خدمــة

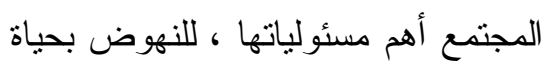

• تؤكد علي البعد الاجتماعي و القيم الثقافية

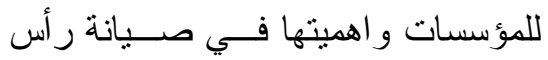

المال الإجتماعي social capital

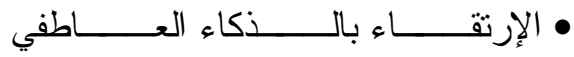

للعـاملين Emotional Intelligence

وتنريبهم علي إدارة عو اطفهم وحـثنهم

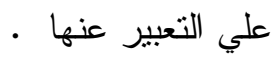

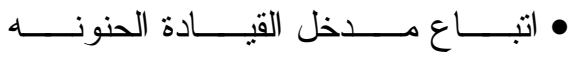

compassionate Leadership

للعوده بالمنظمات الي تكاملها ونو ازنها.

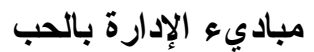

تقوم فلسفة الإدارة بالحب علي خمسة

مباديء ،وهي (1998،Sanford)

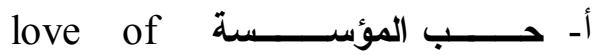

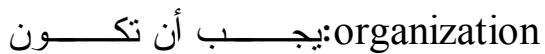

المؤسسة للقائد بمثابة الاســره و البيـــت

لكي يتمكن،من معرفة رسالتها وفهمهــا

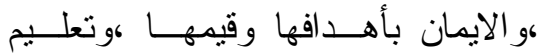

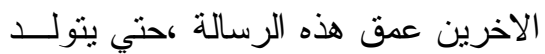

التزام قوي بأداء هذه الرسالة ،وتحقيق

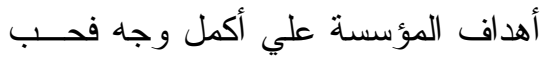

المؤسسة ونجاحها وجهان لعملة و احـده

كو القائد المحب لمؤسـسته هـــو الــذي ونس

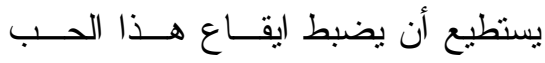

وترجمته الي سلوك أخلاقي برقي بأداء

المؤسسة . 
* يقدرون أن العلاقة مع العاملين تتغيـر

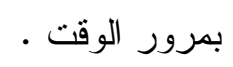

* يعون أن الناس مختلفون ، وأن كل فرد

$$
\text { طريقة خاصة في التعامل. }
$$

* مصدر ارشادي للمعرفه لدي الاخرين.

* لا يتتافسون علي كسب شعبية أ تباعهم * يعرفون نقاط القوة و الضعف في انفسهح وفي العاملين لايهم

* يعطون الاخرين قدر امن الاستقلالية في

$$
\text { الوقت المناسب }
$$

* يشاركون في مناسبات العاملين *

* يشجون الآخرون عند نجاهم ،حتي لو

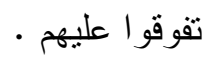

\section{أهمية وفوائد الإدارة بالحب}

تمتل الإدارة بالحب الإهتمام بالعنصر

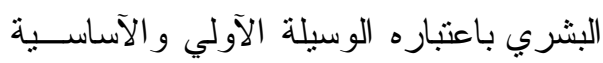

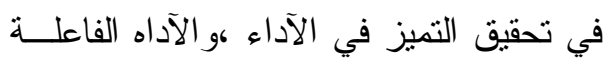

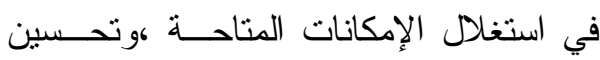
مستوي الآداء ،وتحقيق اعلي معدلات الرضا لدي جميع المستفيدين من خدمات المؤسـسـة

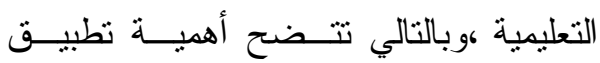
أسلوب الإدارة بالحب مــن خــلال الآتـي لـــي

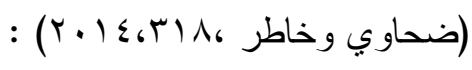

العـــاملين و العدــــلاء و وأســــر هم، لآن

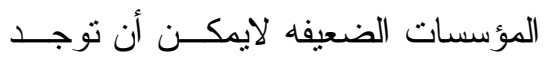

$$
\text { وتتمو في مجتمعات ضعيفه . }
$$

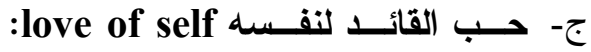

الانسان الــذي يحـبـ ويحتــرم نفـسه

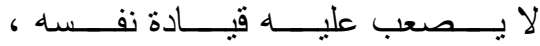

ولا يجد صعوبة فــي قيــادة الآخــرين ،ولكن الحب المقصود هنا هـــو الحـبـ الآخلاقي الذي يخلو من الآنانية وحـب لـب التملكك و السيطرة، وحب الـــات لآنــهـ وســيلة حـبـ ورعايــة الآخــرين ،

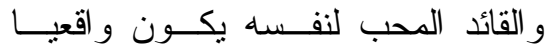

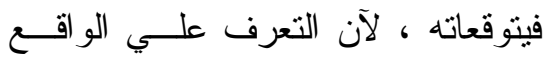

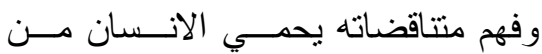
مــشاعر الآســف و النــدم و الاســنتياء و الغضب التي قد تصييه عنــدما يقابلـــهـ

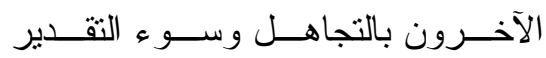
و الإنكار ،لذلك تعتبر الو اقعية و المنطقية من أهم أساليب حب الذات .

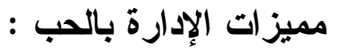

يتميز القادة الإداريون الذين بطبقــون

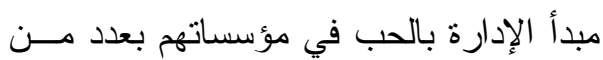

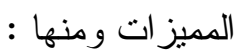

* يتميزون برؤية مستقبلية دون التركيــز

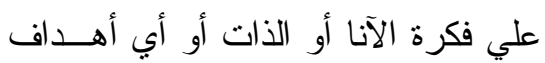
مادية . ماية 


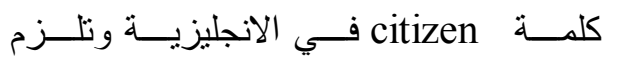
المواطن صفتين الطاعه و المقاومه .قالطاعه

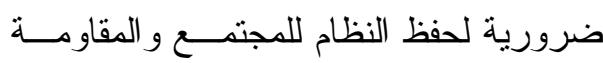

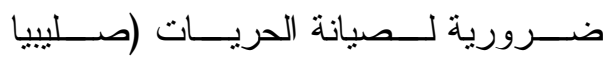

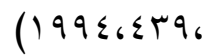

وبالتاللي يمكن القــول أن المواطنـــة مفهوم قديم قدم البشرية نفسها ويمكن رصــد بعض التعريفات التالية للمو اطنة :

العلاقة القانونية بين الفرد و الدولـــة ،

فالمواطنة هي الانتماء للمكونات الاجتماعية

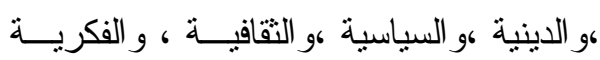

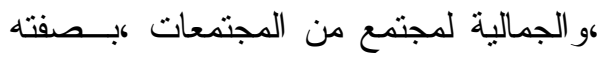
جزءا من مجموعه تحمل في طياتها الثعور لئه

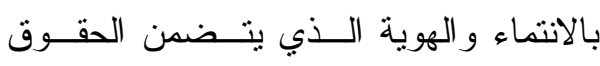

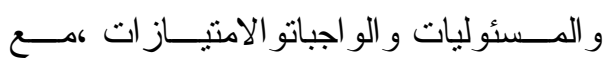

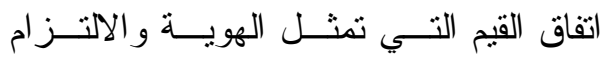

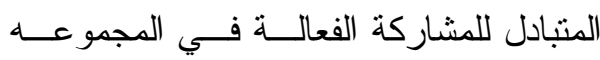
(10،2000،Acara) وتعرف بأنها حق المرء بالعـضوية

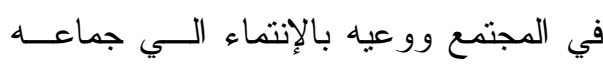

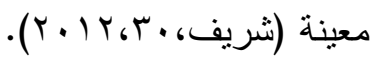

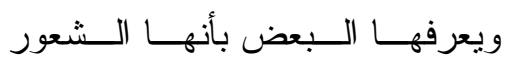
بالإنتماء و الو لاء للوطن و القيــادة الــسياسية

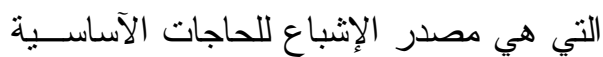

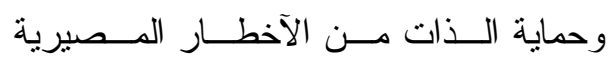

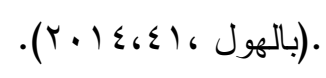

• تهيئة المناخ الذي يحقق أعلي معـدلات الانتاجية ،من خلد التفاعل والإنـسجسام في العلاقات بين الإدارة و العاملين .

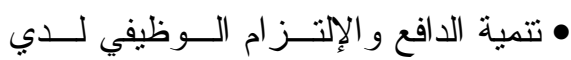
العاملين فــي المؤسـسة ،مــن خــله السياسات الني تكفل منح قيمة للمــــوارد

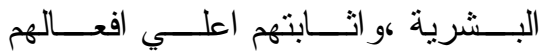

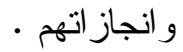

• تشجيع الإلتز ام التتظيمــي مــن خــلال

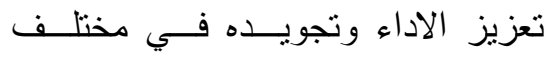
الآقسام و عل مستوي المؤسسة الجامعية. • تدعيم شعور الإنتماء للمؤسسة . • تحقيق شعور التحفيــز وفــرق العمـلـل ،وجودة الحياه الوظيفية . • الآلفة الثديده بين العاملين مما يؤثز الي إنجاز العمل في المرتبة الاولي •

\section{الإطار النظري للمواطنة}

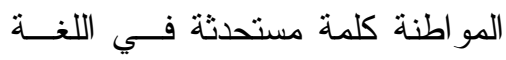
العربية ، وفــي اللغـــة الاتجليزيــة تعنــي

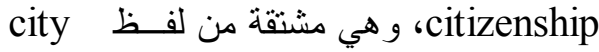

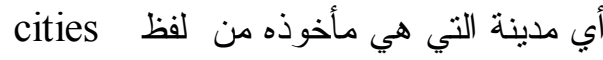

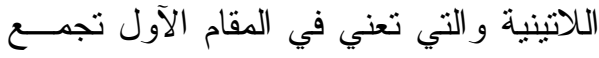

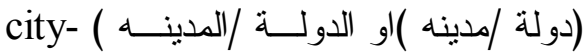

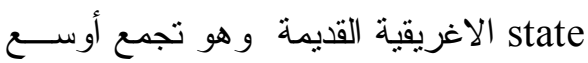
من تجمع المدينة او كلمة مو اطنة مشتقة من

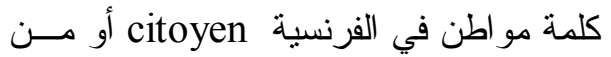




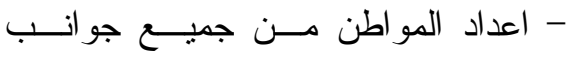

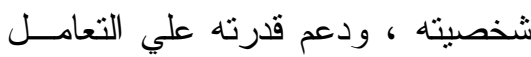

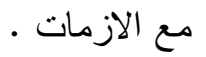

$$
\begin{aligned}
& \text { - العمل علي ضــــان اســتمرار الدولـــة } \\
& \text { و المجتمع ،من خلال تمكين المــواطن }
\end{aligned}
$$

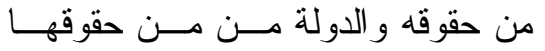

$$
\begin{aligned}
& \text { ،و العمل علي رفعة الدولة وتقدمها - }
\end{aligned}
$$

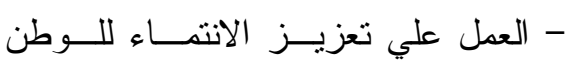

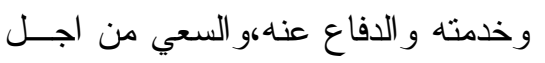

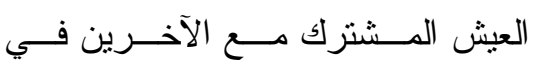

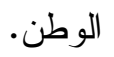$$
\text { صور وأثنكال المواطنة . }
$$$$
\text { توجد عدة أثنكال للمواطنة ومنها : }
$$$$
\text { المواطنة المدنية : من اهـــم نتــائج }
$$

القرن الثامن عشروتـشمل حريـــة التفكيـر

$$
\text { و التعبير و الملكية . }
$$

المواطنة السياسية :ظهـرت مــع

القرن الثاسع عشر ،وتثمل حـق مــشاركة

$$
\text { الفرد في الانتخابات و التشريع • }
$$

\section{المواطنة الاجتماعية والاقتــصادية}

ظظهرت فــي القــرن العـشرين ،وتــشمل المشاركة الي أقصي حد ممكن من الاستفادة

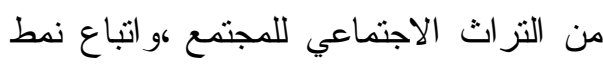

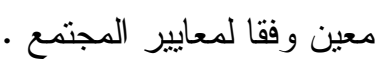

المواطنة الثقافية : وتشمل مفهـوم

المساو اة المشرو عه ضد كل أنو اع التقرقــــة
و المو اطنة في الفكر المعاصر تعنــي

كما تقول دائرة المعارف البريطانية علاقـــة بين فرد ودولة يحددها قانون تلك الدولة ،بما

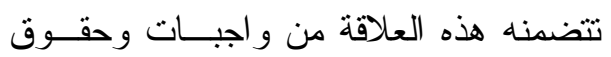
منبادلة في تلك الدولة متضمنة هذه المواطنة مرنبة من الحرية ومايصاحبها من مسئوليات

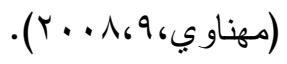

وتعرف أيضـا بانها "علاقــة يكــون

الفرد من خلالها مو اطن أو عضو ا في بـــلاد

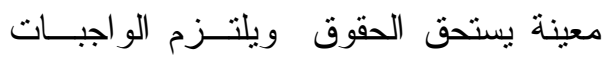

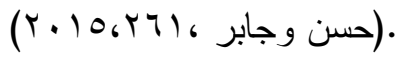

أما مفهوم القيم يعني الإســتقامة أي

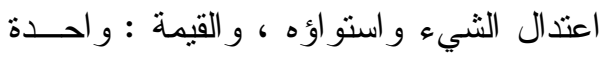
قيم ، يقال تقاوموه فيما بيــنكم ، و اذا انقــاد

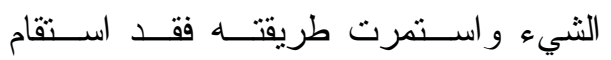

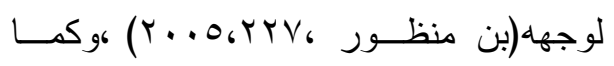
تعرف بانها قوم ، اي تقويما ، 'ويقــول بــن

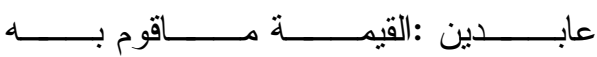

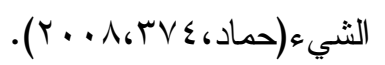
أهداف المواطنة : تهدف المو اطنة الي (محمد واخرون $:(r \cdot) \leqslant 6$ - دعم قيم الو لاء و الانتماء وتعزيز ها لدي

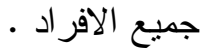
- تحقيق المساو اة الكاملة بين الجميع فــي

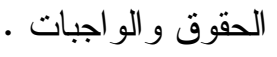




$$
\text { ،و احتر ام ثقافة الاخرين ،والــوعي بــالتزاث }
$$

تعتبر قيمة الـــولاء صــفه أساســية

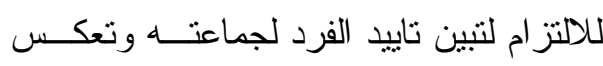

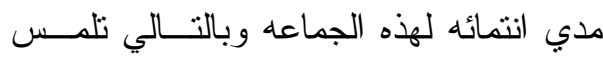

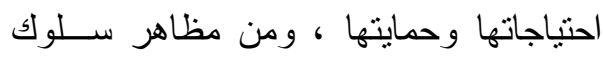

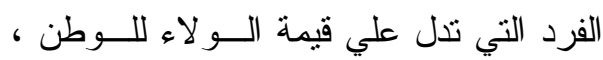

رعاية الممتلكات العامة وحسن اســتخدامها لتاهي

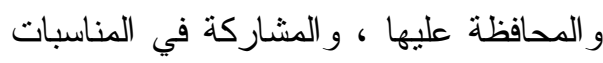

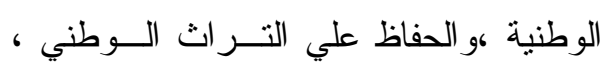

واحترام القوانين ومحاربة النطرف بجميــع

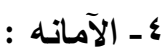

تعتبر الآمانة مــن أهــم عناصــر

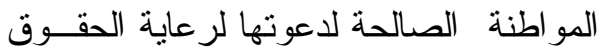
و احتر امها ، وتعني حرص المرءء علــي أداء

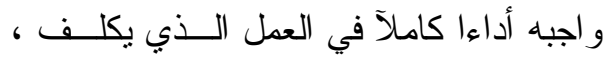
وعدم استغلال منصبه في منفعه لشخصده او احد اقاربه ، و المحافظة علي اسرار الوظيفه

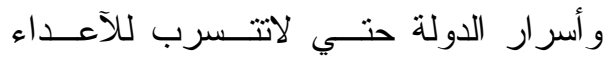

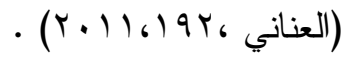
هـ الحرية :

وتعني القدرة علي اختيار مانريد في الوقت نفسه ، مع التعمتع بقرة ممانلة علي عدم اختبار مالا نريد ،وتعتبر اهميتها كأهمية

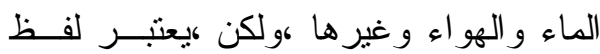
الحرية من بين الالفاظ الغامضة ،حيث يعتقد

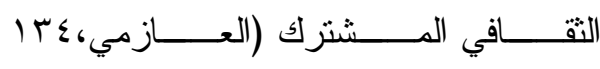

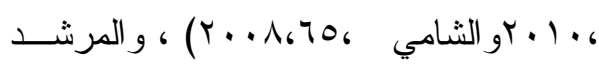

$(r+9,9)) \cdot 6$

ومن ابرز قيم المواطنة التي ينبغي

غرسها في نفوس أفر اد المجتمــع مـــايلي

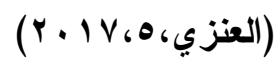

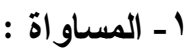

تعتبر المساو اه مــن أهــم الاسـس الهـ

و المرتكز ات الجو هرية للمو اطنة في الــدول المتقدمة ،حيث تتيح للآفر اد التتنع بحقــوقهم و القيام بو اجباتهم ،ومن خلال المساواة فــي لئحي

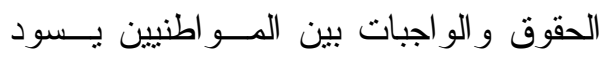

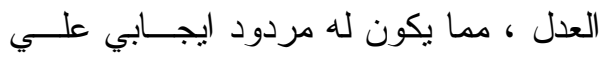

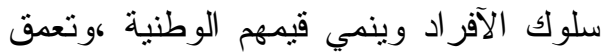
لديهم قيمة الاعتز از بالوطن و التضحية مسن

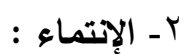

يعرف الإنتماء بأنه الإنتساب الحقيقي

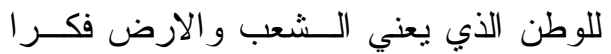

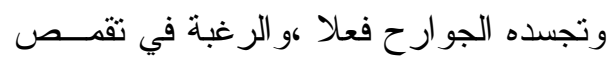
عضوية ما لمحبة الفرد لــــلك و الاعتــزاز بالانضمام للوطن و الذي يعبر عــن الــصلة

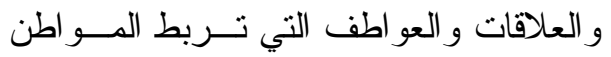

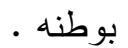




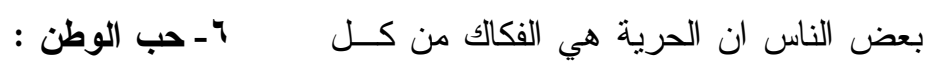

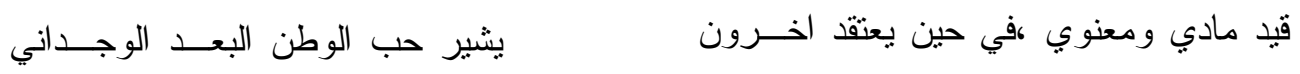

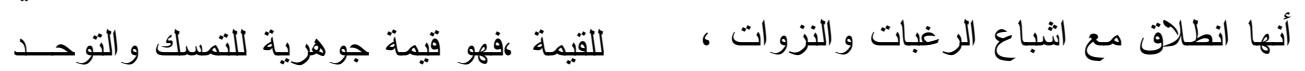

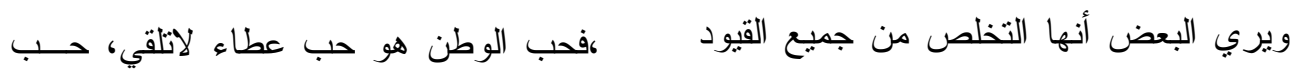

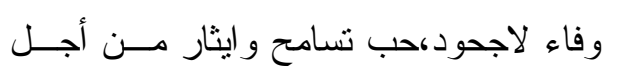

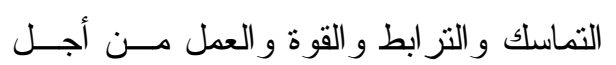

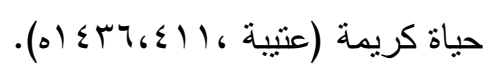

حب الوطن هو غريزة فطرية ،لآتــهـ

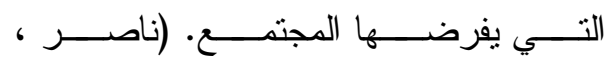
(r...r. (T) ويمكن توضيح الحريات وانواعها كالتالي :

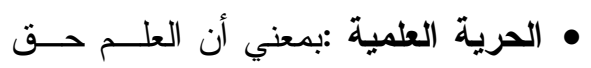

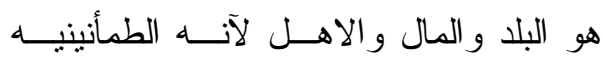

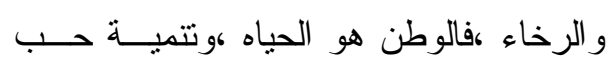
الوطن لنبابنا ،سيؤدي الي الاهتمام بالوطن وقضاياه ،ويمكن الفرد من العمل والانتــاج و الحفاظ علي ممتلكات هذا الوطن .

ومع التطـــورات الــسريعة العلميــة و التكنولوجية ،يجب غرس حب الوطن فـي لوني نفوس طلابنا ،عن طريق تزويدهم بالمقومات

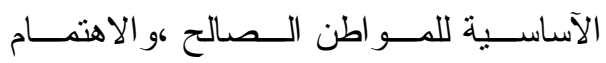
بالتوعية الدينية ونــشرنقافة حـب الــوطن بطريقة صحيحة . بالتوعة للائه ون V - المسئولية :

وتعني استعداد الفرد للقيام بما يوكــلـ عليه من و اجبات في المو اقف المختلفة ،وهنا المسئولية تركز علــي الجانــب الـــلوكي

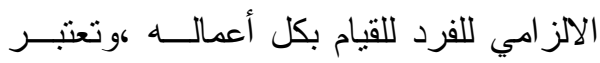

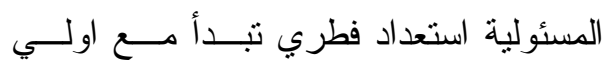
خطوات الفرد بداية من الاسرة فالروضة ثم

• الحرية الفكرية :وتعني حرية التفكير في

$$
\text { موجودات الكون }
$$

• الحرية السياسية:الحق في الاشتر الك في

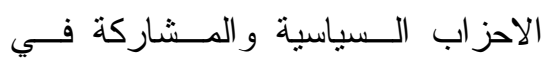

$$
\text { الانتخابات. }
$$

• حرية العمل :حق الانسان في أن يعدـل

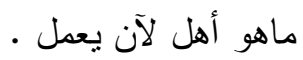

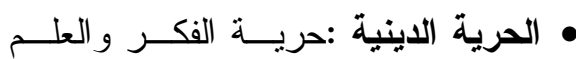
للانسان في الوصول بكامل ار ادته الــي لـي لـي

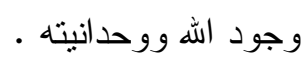
فالحرية هي القدرة علي الاختبار بين

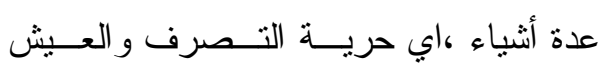
و السلوك حسب توجيه الار ادة العاقلـــة ،دون

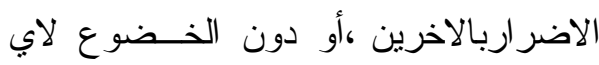
ضغط الا مافرضته القوانين العادلة وواجبات

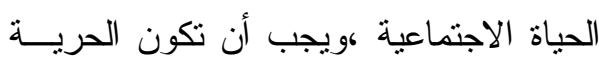
منو ازنه مع المسئولية التي يضطلع بها الفرد في حدود استعداداته وقدر اته . 
الحرية و العدالة ،وتحقيق التتمية المجتمعيــة والسعاده لكل افر اد المجتمع وليس كل افراد علي حده. مداخل تنمية قيم المواطنة .

يوجد عدد من مسـداخل تتميــة قـيم

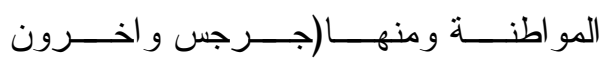
$:\left(r_{*} \cdot v_{6}\right) \cdot A_{6}$

Academic مدخل المجالات الاكاديميـــة .Dsiciplines Approach

يعتمد هذا المــدخل علــي تـدريس

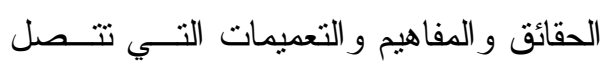

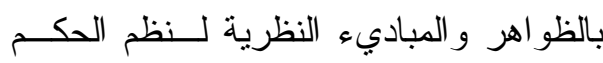
و الديمقر اطية وسلوك المو اطنـــة و المفــــاهيم المدنية و السياسية فـي ماضــي وخاضــر

$$
\text { المجتمع }
$$

law -Related . مدخل التربية القانونية Education Approach

يعتمد هذا المــدخل علــي تــدريس العمليات القانونية ودور الطلاب في تطبيــق لهن

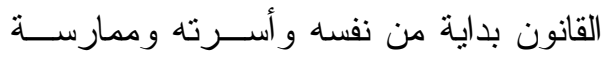

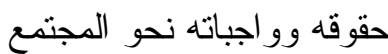

Social مــخل المــشكلات الاجتماعيــة Problems Approach

يقوم هذا المدخل علي دراسة القضايا الو اقعية ،ويقوم بنتجيع الطلاب علي مناقشة القضايا و المشكلات بالتعامل معها باســتخدام

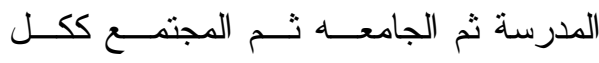
،وتتضح هذه القيمة من خلال ممارسة العديد

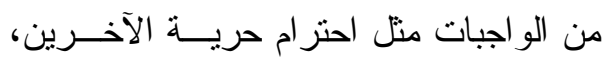

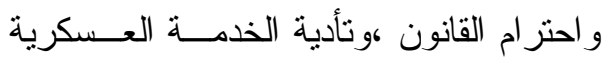
للوطن و الدفاع عنه ،وو اجب دفع الضر ائب . ^- الاحترام :

هو قيمة انسانية عامة تشمل علاقـــة المسلم بغيره وبالمجتمع الذي يعــيش فيـهـ ،ولقد اصدرت اليونسكو مجموعه من القيم بعيرة رأت أنها القاسم المشترك بين الانسانية كلها

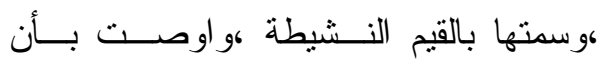

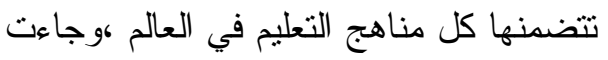

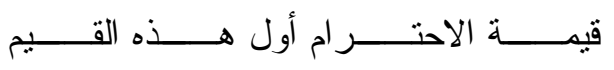

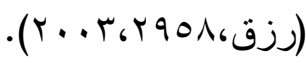

ومن صور الاحتر ام ،احتر ام الــذات

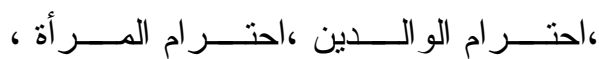
احتر ام المجتمع ،احتر ام العلمـــاء ،احتـــرام

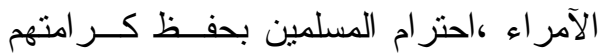
و أدميتهم الاهراء

بناء علي ماسبق يمكن القـــول أن أبي مجتمع انساني يتمتع بهذه المفــــاهيم الر اقيـــة

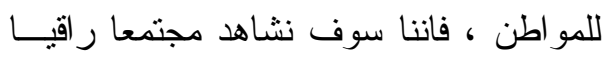

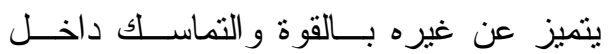

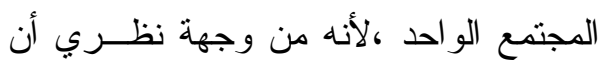

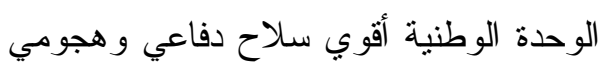

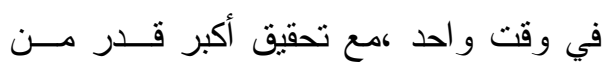


critical Thinking • مدخل التفكير الناقد

Approach

يساعد هذ المدخل الفرد علي التفكيـر

التي تساعده علي تحديد القضايا و التمييز بين مختلف أنو اعها ،وتتمية الاستدلال المنطقـي و اصار الاخكام القيمية .

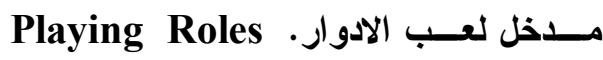

Approach

احد اثنكال التصوير الــدرامي التـي

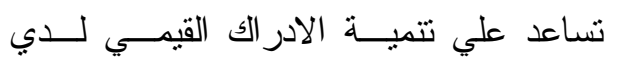

الطلاب اثثاء عرض المشكلات وتقديم حلول

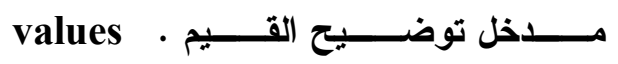

\section{Clarification}

يقوم هذا المدخل بمـسـاعدة الطــلاب

علي توضيح بعض القيم والاختيار فيما بينها من خلال القيام بالاختيار الحر للقيمة من بين

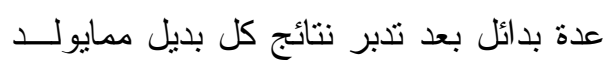

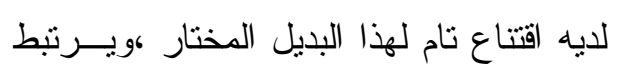

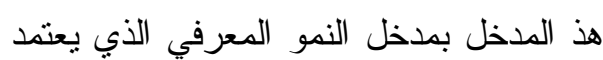

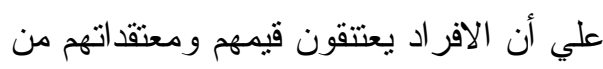
خلال التفكير و الاستدلال.

Comparative • مدخل التحليل المقــارن Analysis Approach

يعتمد علي دور الطلاب في المقارنـــهـ

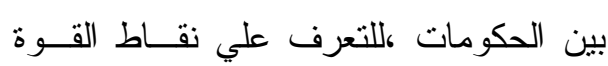

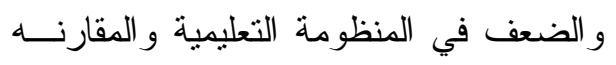

العقل مع تقــديم أر ائهـــم وطـــرح الحلـــول

$$
\text { المقترحة لها مالعيا }
$$

Institutional . مدخل الادارة الجامعيـة لمنة University Reform

يقوم هذا المدخل علي مبدا أساسي بأن

الحياة الجامعية لها تأثثر أكثر من أب شيء

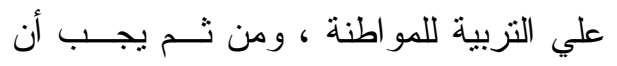

يسمح للطلاب بتحمل المسئولية و المــشاركة

في اتخاذ القرار في مدارسهم ويتضمن هــــا

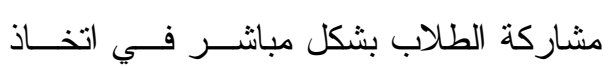
قر ارات في بعض القضايا التربوية

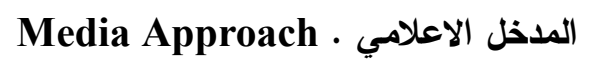

من المعروف أن هنالك علاقية تكاملية

بين التعليم و الاعلام ،هذه العلاقة تساهم فــي هني جعل الطلاب أكثر اهتماما بالقضايا السياسية

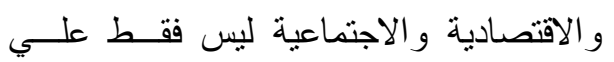

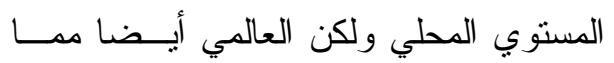

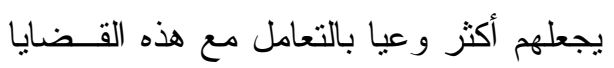
من خلال الدور الذي تقوم به وسائل الاعلام في احداث التغير الاجتماعي بصفه عامة

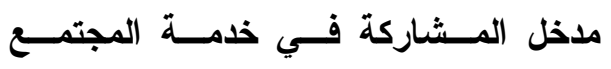
Community Involvement . Approach

يركز هـــا المــدخل علــي البيئـة

الاجتماعية التي يعيش فيها الطالب من خلال خدمة البيئة و الحفاظ علي تز اثها وخضارتها لتها

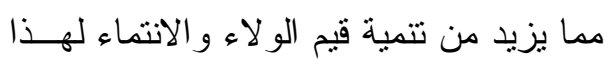
المجتمع 


$$
\begin{aligned}
& \text { • تكوين الإتجاهات الإيجابية السليمة نحو } \\
& \text { بموضو عية بعيده عن التحيز لأي حكومسـة أو } \\
& \text { حب الوطن و التضخية من اجلــة مـــع الإنع }
\end{aligned}
$$

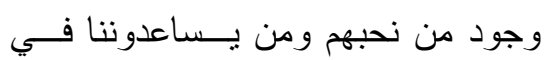

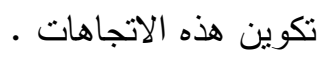

$$
\begin{aligned}
& \text { منطلقات التصور المقترح. } \\
& \text { • طلاب التعليم الجامعي هم الثباب الذين }
\end{aligned}
$$

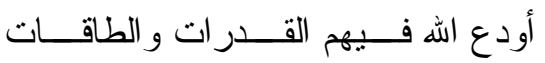

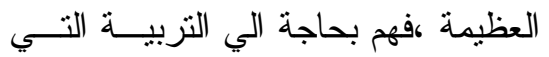

$$
\begin{aligned}
& \text { تشمل جميع النواحي الجسمية و العقليــة }
\end{aligned}
$$

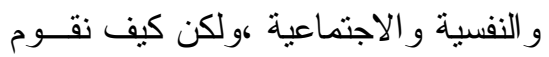

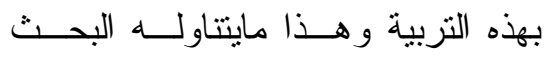

$$
\begin{aligned}
& \text { الحالي عن طريق الإدارة بالحب ،ولهذا }
\end{aligned}
$$

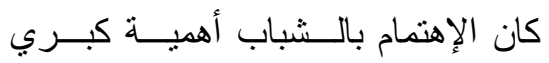

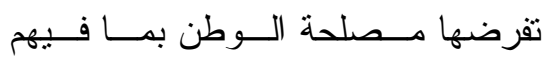

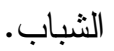

$$
\begin{aligned}
& \text { • دعم نقافة الإدارة بالحب ،فكثير ا بنفتقـــ }
\end{aligned}
$$

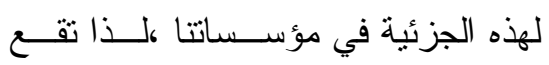

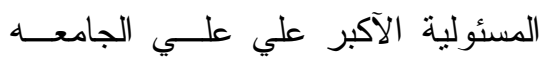

$$
\begin{aligned}
& \text { ،لآنه داخل كل بيت يوجد أحد أفر ادهــا }
\end{aligned}
$$

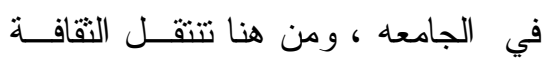

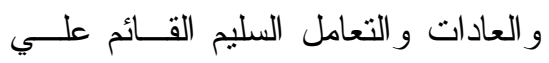

$$
\begin{aligned}
& \text { المنهج العلمي ،وبالتالي لا يمكن اغفــال ولعال }
\end{aligned}
$$

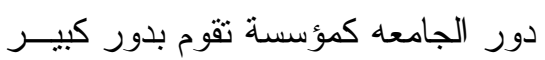

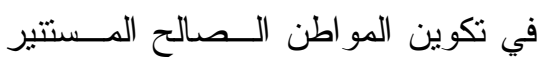

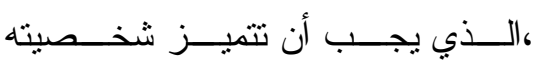

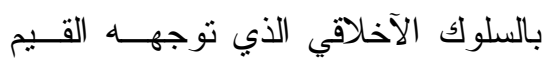

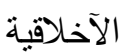

$$
\begin{aligned}
& \text { تصور مقترح لتفعيل الإدارة بالحب كمدخل } \\
& \text { لتتمية قيم المواطنة لـــي طــلاب التعلــيم }
\end{aligned}
$$

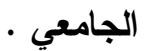

$$
\begin{aligned}
& \text { يمكن وضع تصور مقتــر ح لتفعيــل }
\end{aligned}
$$

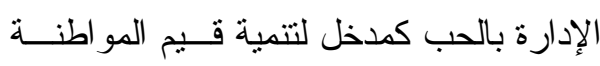

$$
\begin{aligned}
& \text { لاي طلاب التعليم الجامعي ،ولكن هذا الآمر }
\end{aligned}
$$

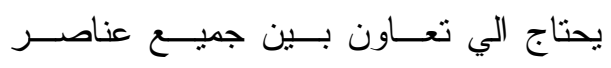

$$
\begin{aligned}
& \text { المنظومة التعليمية في التعليم الجامعي علـي لـي لعي }
\end{aligned}
$$

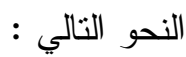

$$
\begin{aligned}
& \text { أهداف التصور المقترح : }
\end{aligned}
$$

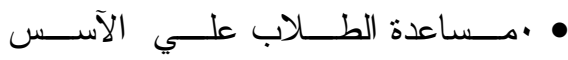


القائمة علي أسس الديمقر اطيــة ،وقــيم المساو اة و العدالـــة ،و التوزيــــع العـــادل

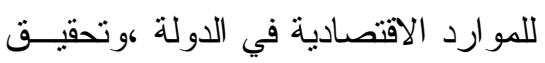
مبدأ تكافؤ الفرص الفص الفصاد

- الاهتمام بالثقافة الساسية بما ينمي لــدي

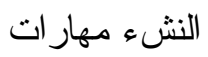

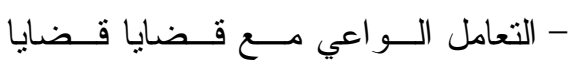
- المجتمع المعام

- اقامة ندوات نوعويسـة مـشتركة بــين

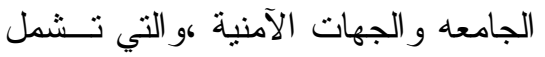

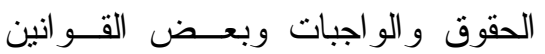
والنظم الدستورية المنظمة للحياة المدنية

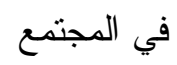
- تفعيل دور أجهزة الاعلام بالجامعه فـي

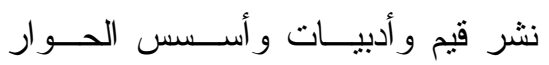
الموضوعي البناء .

- تبــين الادارة الآتـــار المتزتبـــة علــي الانحــر اف الفكـــري، وتــصحح ادارة

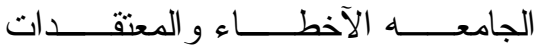
و الآفكار المضللة .

- تكرم الادارة الطلاب المتميزين سلوكيا دور أستاذ الجامعه في في تفعيـل مــــلـ الإدارة بالعب لتنمية قيم المواطنــة لــدي

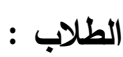
- أن يتسم عضو هيئة التدريس بـالجمع بين الجانب الانساني و الجانب المهــاري
• التوجهات العالمية المعاصرة للتربية في الآلفية الثالثة ،التـي تـدعم مـن قـيم المو اطنة في الإيجابية في المجتمعـات الديمقر اطية

أليات التصور المقترح.

(أ) توفير المناخ الجـامعي القـائم علـــي

الإدارة بالحب لتدعيم قيم المواطنة من

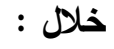
- أن يتميز هذا المنـــاخ بدعمـــه للتقافــة الاسلامية ثم الوطنية ،و أن يكون منو افق بدع

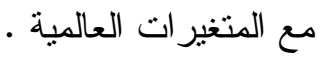

- أن يكون المناخ الجامعي قــادر علـي لــي تجسيد القيم و السلوكيات التي تدعم قــيم

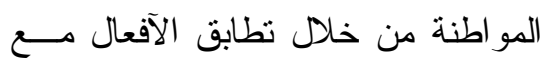

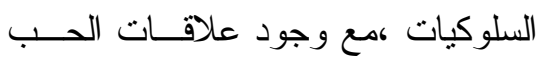
و المودة و الثفافية و العدالة الاجتماعية - بذل المزيد من الجهود في تعليم الطلاب

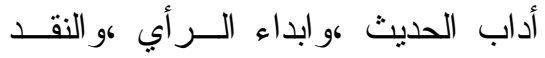

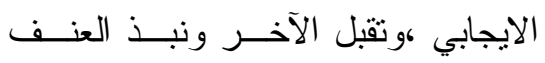
و التطرف ،و احتز ام مـشـاعر الآخــرين

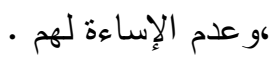

دور إدارة الجامعه في تفعيل مـــخل الإدارة بالحب لتنمية قيم المواطنة لدي الطلاب . - تدعيم المنظومة القيمية فــي المجتمــع المصري من خلال الآخذ بالاتجاهــات

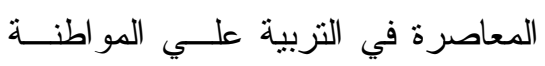


بمعايير المجتمع والـشعور بالانتمــاء ومفاهيم المساو اة ،و الحرية .

(ه) الآنشطة الطلابية كالية في تفعيل الإدارة بالحب في تنمية قيم المواطنة

- عقد ندوات ولقاءات حوارية مع بعض النماذج من الثخصيات الوطنية البارزة

- مباركة أعضاء هيئة التذريس و الطلبـــة

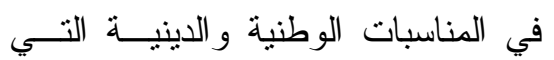
تحيي مشاعر العطاء وكيف يكون حسب الوطن

- توفير الآفــلام الوثائقيـــة والتاريخيـــة و الثقافية للطلاب توفيز الاب

- عمل أيام تطوعية من قبل طلبة الجامعه

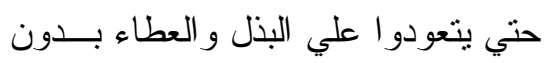
مقابل . مابل

(و) الاتحادات الطلابية كألية لتفعيل مـدخل ملابل

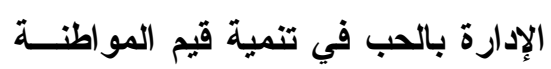
لاي الطلبة . - تفعيل الإتحادات الطلابية داخل الجامعه مما يعطي الطلاب فرصة المشاركة في

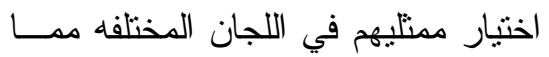
يساعد علي تتمية قيم المو اطنة

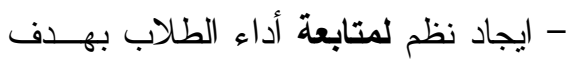

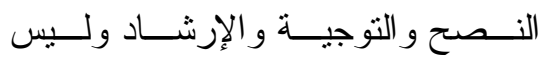
المحاسبة
في التعامل من خلا العلاقات الانسانية

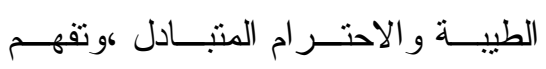

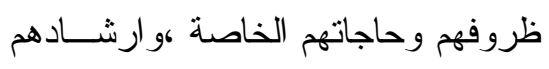
بما يتو افق مع قيم المجتمع ،ومساعدتهم

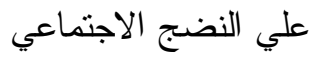
- أن يتعامل أعضاء هيئة التدريس بقــدر

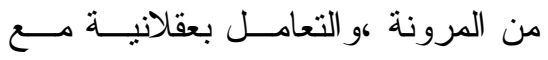
الطلاب لان الآستاذ الجامعي يدخل كـلـل بيت بسلوكه ومعتقداته و أفكاره ه ل - أن يغرس عضو هيئــة التــدريس فـي

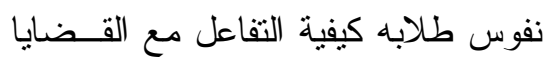
الوطنية ،و الحفاظ علي المصلحة العامة للوطن (ج) المناهج الجامعية كألية لتفعيـل الإدارة بالحب في تنمية قيم المواطنــة لــدي الطلاب - ربط المحتوي النظري للمقرر الدراســي

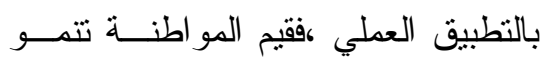

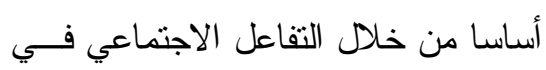
المو اقف المختلفه . - أن تشمل جميع الدقـررات الدراســية

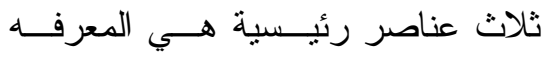

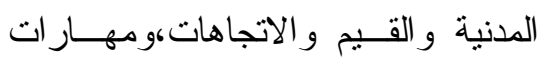
المشاركة المجتمعية الفاعلة . - أن تتضمن الدقــررات الدراســـة قــيم المو اطنة كالروح الجماعية ،و الالتــز ام 
• مؤسسات المجتمع المدني :ثقوم بــدور

كبير من خلال نـشر نقافــة المو اطنـــة

بالتعـــاون مـــع الجامعــات و التتظيمــات

السياسية من خلال التخلص مــن اتبــاع

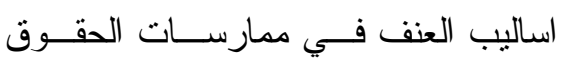

،وتتظيم لقاءات ومؤتمرات خاصة بطلبة

الجامعات حول أهمية الوحـــدة الوطنيـــة

$$
\text { وتعزيز ها - مان }
$$

التوصياث

• تبني وزارة التعليم العالي مــدخل الإدارة بالحب ،ضمن الدور ات التدريبية التي تقدم لاعضاء هيئة التدريس

• تدريس مــدخل الإدارة بالحــب ضـــن

متطلبات بر امج الدر اســات العليــا فــي

تخصـــصات الادارة و أصــــول التزبيــــة

$$
\text { و التزبية المقارنه }
$$

• قيام القيادات الجامعية بزيـــادة الاهتمـــام

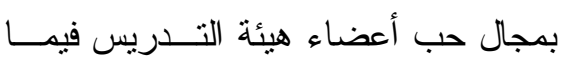
يخص صنع و اتخاذ القرارات ،وتوزيــع المهام و المسئوليات عليهم بما ينلائم مــع تخصصاتهم و احتياجاتهم،وتفعبـلـل نظــام تبادل الأساتذة الز ائرين بــين الجامعــات ومعاهد التعليم العالي .

• اجر اء دراسات مماتلة باستخدام متغيرات مستقلة جديدة للتعرف علي درجة ممارسة القيادات الجامعية لمباديء الإدارة بالحب.
(ز) الجهات المشاركة في تتفيــذ التــصور المقترح

يقترح الباحثان عدد من الجهات المــشاركة في تنفيذ التصور المقترح كما يلي :

• الآسرة :أهم مؤسسة في حياة الفرد بشكل عام فعن طريقها تغرس البذور الآولي في نفوس أو لادها ،فيجب تربية او لادهم تربية

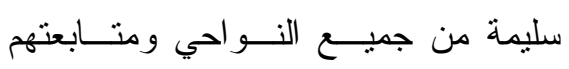
ومناقتتهم لمعرفة مايدور في أذهانهم ،مع تزبيتهم علي الـشوري حيــث أن هــذه التزبية تعمل علي تتميــة قــيم التـسـامح و الحوار وتقبل وجهات النظر وهذا هـــ المطلوب

• وسائل الإعلام :تقوم بدور كبير فيدعم قيم المواطنة من خلال نشر ثقافــة التعامــلـل الانساني المهاري بالإدارة بالحــب فـي

$$
\text { تتمية قيم المو اطنه }
$$

• المؤسسات الدينية :يقع عليها دور كبيـر في تتمية قيم المواطنة من خلال رجـال الدين في تعزيز قيم المواطنة من خــلال نبذ العنف و التطـــرف ومو اجهـــة الفكــر

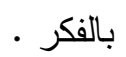
• المؤسسات الامنية :أن تعدــل القيــادات الامنية علي تقوية العلاقات الايجابية بينها وبين المـــواطنين فـي تطبيــق القــانون و احتر ام حقوق الاخرين دون تمبيز • 
غرس قيم المواطنة الصالحة من وجهة

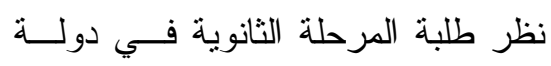

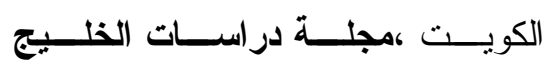
و الجزيرة العربية ،مجلس النشر العلمي بجامعة الكويت ،العدد (r ( )).

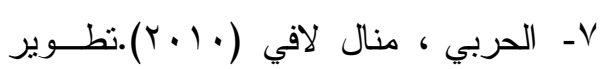

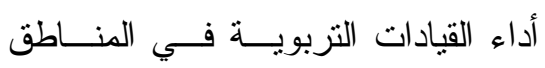

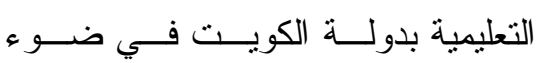
الاتجاهات الادارية المعاصرة ،رســالة

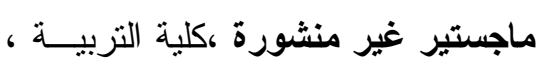
جامعة طنطا.

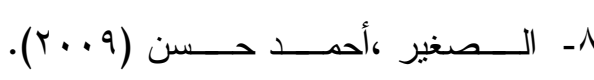
مجتمعات الـتـعلم -نمــوذج لتحسـين

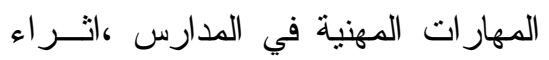
للنشر و التوزيع ،عمان ،الآردن

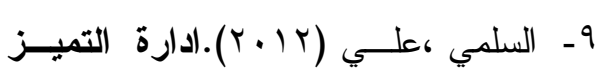

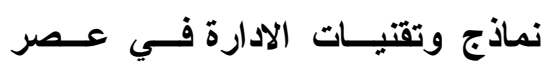

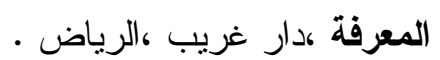

• اــالبحبــري ،الــسيد الــسيد محمـــود .

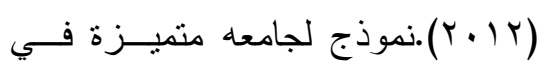
ضوء مؤشرات التميزو الجوده النوعية

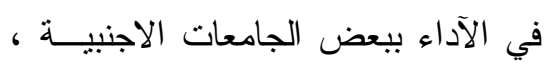

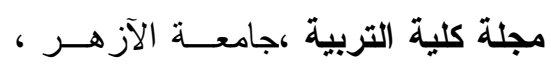
العدد (10.).

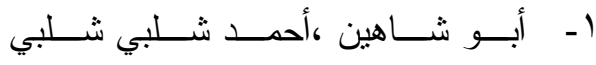

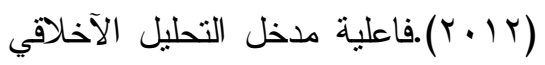

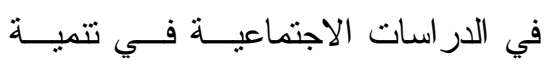
مهار ات التفكير الناقد وقيم المو اطنة لدي طلاب المرحلــة الاعداديــة ،رســالة

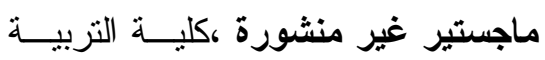
بدمياط ،جامعة المنصوره ،مصر .

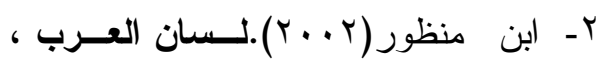

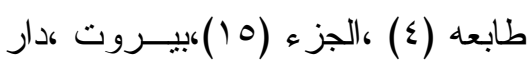

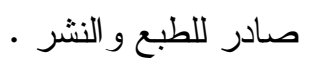
r- ابن منظور ،أبي الفضل جمـــال الــدين

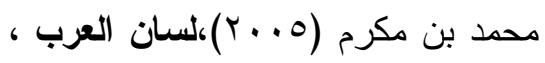

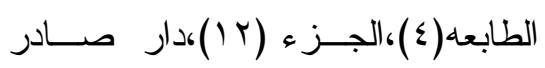
للطباعة و النشر كبيروت .

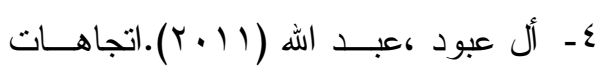

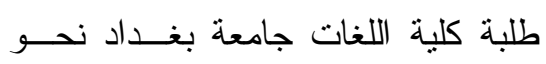
ممارسة النشاط الرياضي ،مجلة علــوم

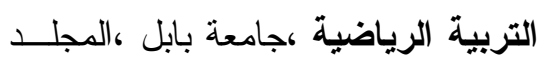

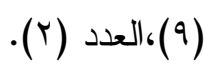

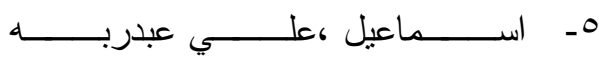
(Y.V.V) في ضوء بعض الاتجاهات المعاصرة ، الاسكندرية ،دار الجامعه الجديده. 7- الثر عه ،ناصر ابر اهيم و الدويلة ،عالية

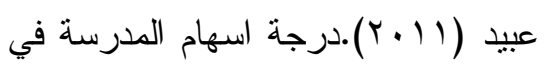




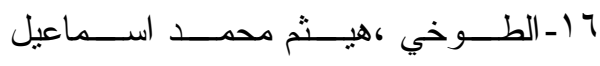

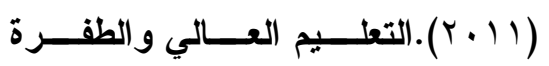

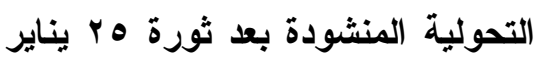

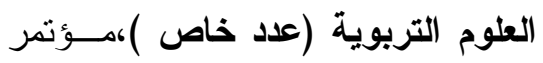

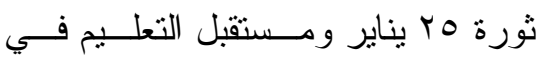

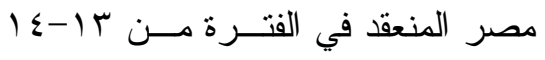

يوليو ،معهد الدراسات التربوية ،جامعة القاهرة ، المجلد (9 (1).

V V ا المنيزل ،عبد الله فلاح و العتوم ،عـدنان سيف (· • • (Y).مناهج البحث في العلوم التربوية والنفسية ،عمان ،اثز اء للنشر

$$
\text { و التوزيع }
$$

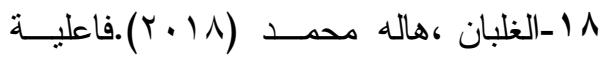
برنامج كمبيوتز متعددالوسائط في تتمية القيم الوطنية لاي عينة دـن الطالبــات

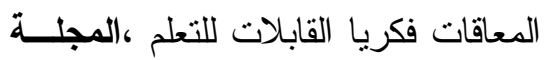
العربية لعلوم الاعاقة والموهبة ،كليــة

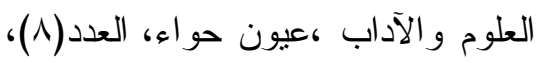

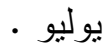

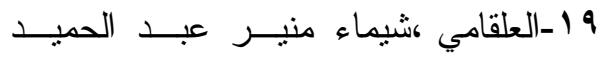

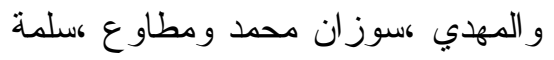

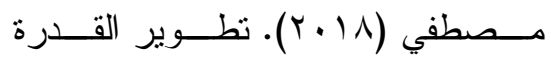

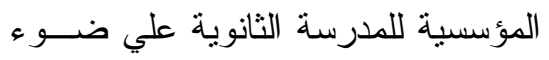
مدخل الادارة بالحب ،المؤسسة العربية

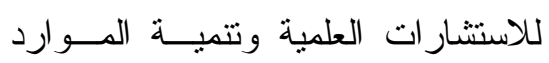

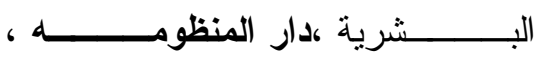

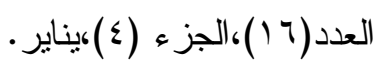

1 ا ـ الضلاعين ،علي فلاح (1/ • ب). معايير

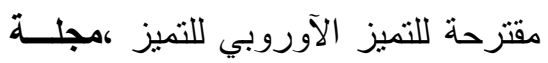

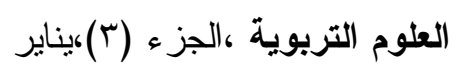

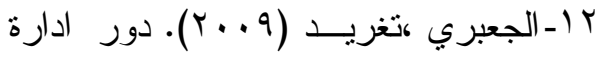

التميز في تطوير أداء مؤسسات التعلــيم

العالي في الــضفة الغربيـــة ،رســـالة

ماجستير غير منشورة ،جامعة الخليل ،

$$
\text { فلسطين ماجسئر عير }
$$

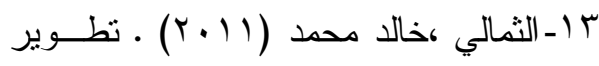
الآداء الاداري للقيادات الجامعية بجامعة الملك عبد العزيز في ضوء مدخل ادارة التغيير ،رسالة ماجستير غير منشورة

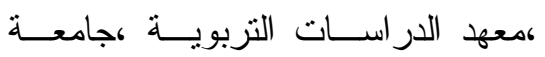

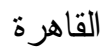

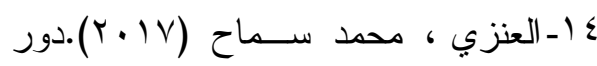
معلم المرحلة الثانوية في تعزيـز قــيم المو اطنة لدي الطلاب من وجهة نظــــر المشرفين التزبوبين ،مجلة كلية التربية،

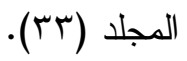

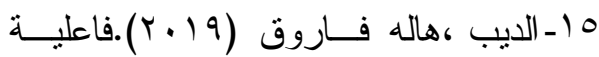
برنامج كمبيونز منعدد الوســائط فــي

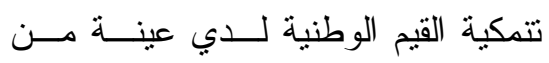
الطالبات المعاقات فكريا القابلات للتعلم، لتهنه المجلة العربية لعلوم الاعاقة والموهبة

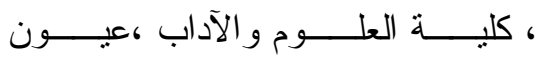

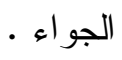




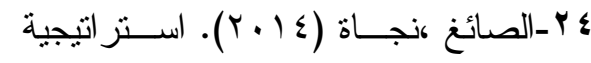

مقترحة للجامعات السعودية في تتميــة

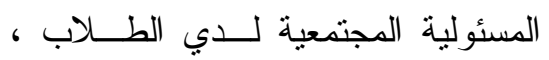

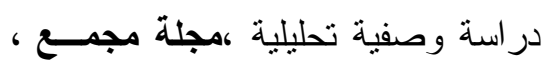

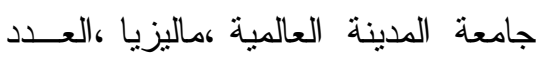

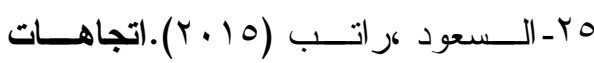

معاصرة في القيادة التربوية :القيــادة

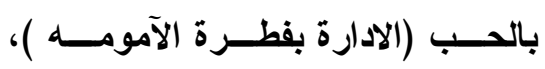

المؤتمر الدولي الآول :التزبيـــة أفــاق

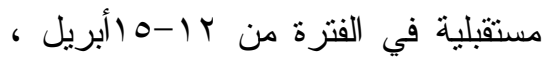

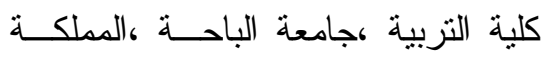

$$
\text { العربية السعودية . }
$$

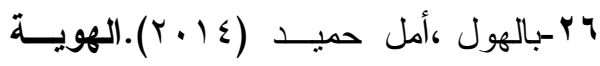

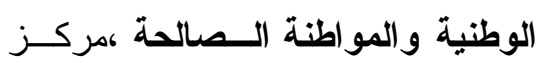

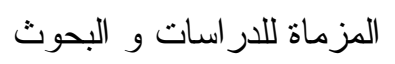

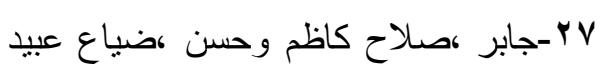

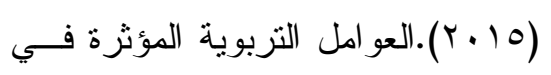

غرس وتتمية الوعي بالمو اطنة ،مجلـــة

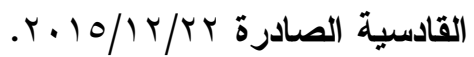

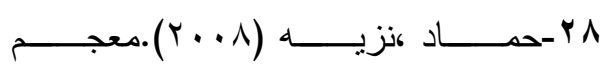

المصطلحات المالية و الاقتصادية في لغة

$$
\text { الفقهاء ،دار القلم :دمشق }
$$

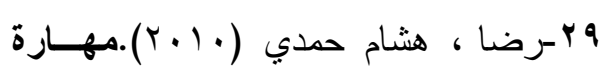

الاتصال والقيادة الادارية ،دار الر اية

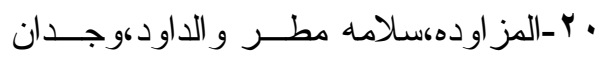

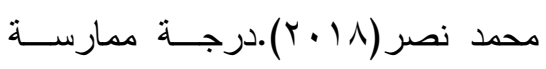

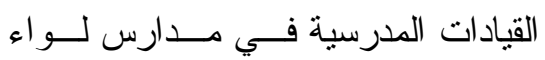

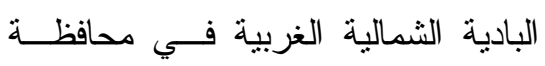

المفرق لمباديء القيادة بالحب من وجهة لئه

نظر المعلمين و المعلمات ،مجلة كليــة ملئة

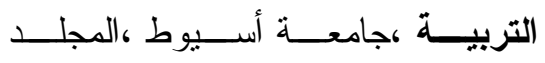

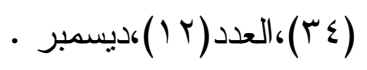

ا ب-الجهني ،رسمية عياد و الغيث ، العنــود

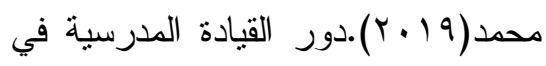

تعزيز الآمــن الفكـري وتتميــة قـيم

المو اطنة لدي طالبات المرحلة الثانويـــة

بالمدينة المنورة ،المجلة العربية للعلوم

التربوية والنفسية ،المجلد (r)، العـدد

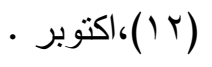

r Y-الآمير ،ايمان بنت حسين بـن الحسـن

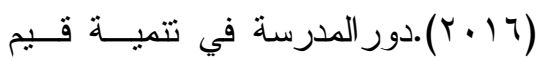

المواطنة لدي طالبات المرحلة الثانوية

من وجهة نظر المعلمات فــي المملكـــة

العربية الــسعودية ،المجلـــة الدوليــة

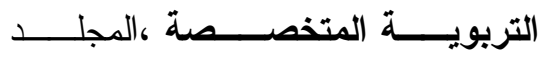

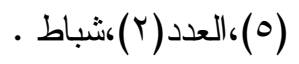

بr

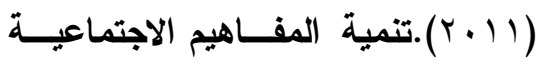

والآخلاقية والدينية في الطقولة المبكرة كدار الفكر ،عمان ،الاردن . 
هب-ضحاوي ،بيومي محمد وخاطر ،محمـد

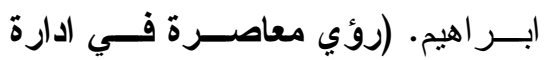

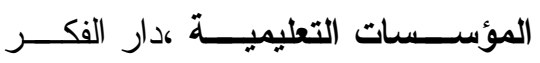

$$
\text { العربي، القاهرة }
$$

بس- عثيبه ،فتحي درويش و عمارة ،ســامي

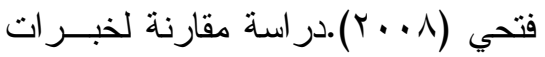

بعض الدول في تحويل الجامعــة الــي

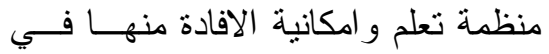

مصر ،دراسات في التعلــيم الجـامعي

كمركز تطوير التعليم الجامعي ،جامعسـة

$$
\text { عين شمس ،العدد (9 ( )،ديسمبر }
$$

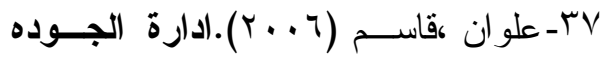

الشاملة وامكاتية تطبيقها في التحـدي

،المؤتمر الخامس جودة التعليم الجامعي

في الفترة من الأبريل ،جامعة البحرين

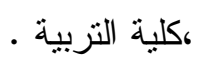

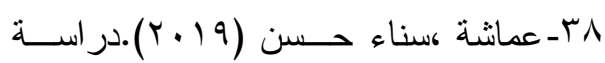

استطلاعية لاسهامات جامعة الطائف في

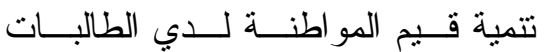

و أثر هذه قيم المواطنة و أثنر هذه القيم في

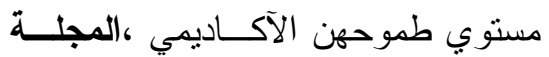

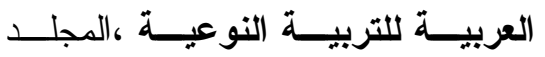

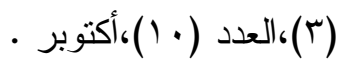

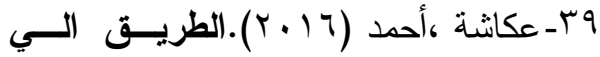

الــسعادة ،القــاهره ،الكرمسـة للنــشر

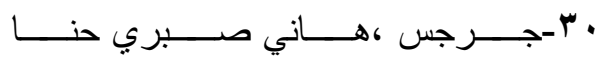

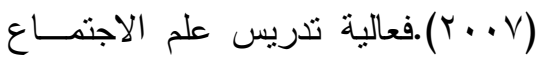

باستر اتيجية العصف الذهني علي تتميــة

قيم المو اطنة و الوعي بــبعض قـــايا

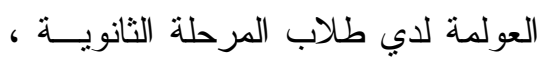

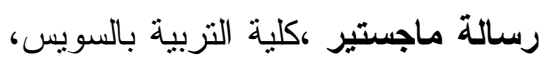

جامعة قناة السويس

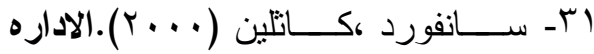

بالحب :كيف تفوز المنظمات بالحنـــان

و القيادة والفطرة ،كتب المدير ورجـال

الآعمال ،العدد(V9 () )،السنه (^)،يونيو •

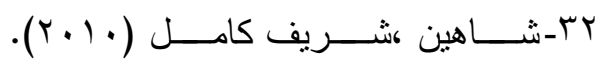

الجامعات العربية بين مطالب الهويـــة

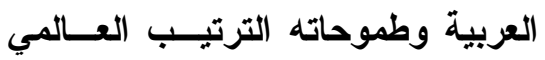

جامعة القاهرة نموذجا ،بحــث مقــدم

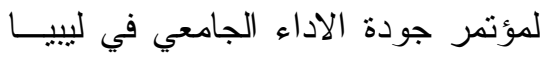

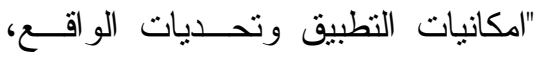

جامعة قاريونس كبنغازي ع -7 ديسمبر .

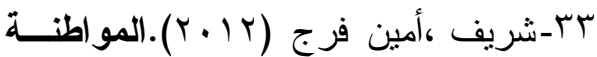

ودورها في تكامل المجتمعات التعددية،

دار الكتب القانونية ،المحلة الكبري

ع ז-صليبيا ،جميل (ع 99 1).المعجم الفلسفي

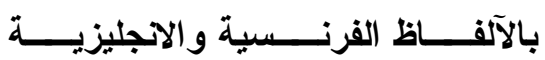

و اللاتينية، الجزء(ب)،الــشركة العالميــة

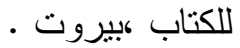

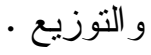


،در اسة تحليلية ناقدة ،مجلة كلية التربية

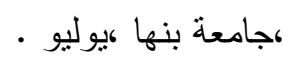

0ـ-يوسف ،نجلاء محمـــ الـسيد محمـد

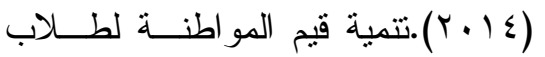

التعليم الثانوي العام في ضوء التحولات لات التهو

السياسية المعاصرة للمجتمع المـصري

،مجلة كلية التربية ،جامعة بور ســعيد

$$
\text { ،العدد(7 ( ) كيونيه . }
$$

7 ك-وينستين ،مان (997 (1).الادارة المرحة

الضحك في بيئة العمل :حيلة ووســيلة

خلاصـات كتب المدير ورجل الاعمــال

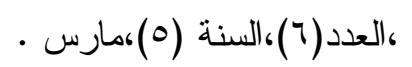

47-Acara،(2012).civics

and

citizenship sthe shape of the

Australian curriculum،sudeny،

copyright administration ‘p. 10 .

48-Taylor، A،\&Marri، A(2012). making sence of citizenship، urban middle and high school students rexperiences with and perspectives on active and engaged democratic citizenship ،ohio social studies review ، 48(1).

49-Mendel‘k،(2002).Examining the impact of university international programs on active citizenship :the case of student paraxial participation

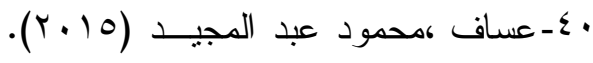

و اقع ادارة الابداع كمدخل لتحقيق الميزة

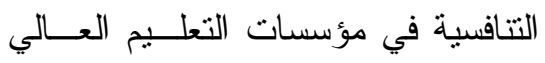

بمحافظات غزة و اســتر اتيجية مقترحسـة فئة

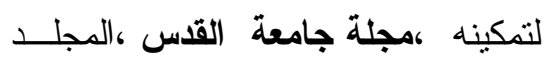

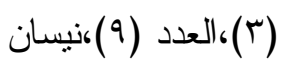

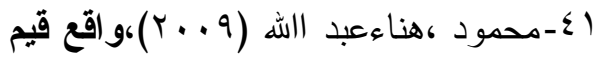

المواطنة في مناهج التربية الوطنيـة

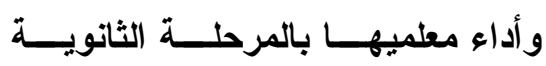

،المؤتمر العلمي الرابــع الــدولي الاول

بعنوان "التعليم وتحديات المستقبل "،كلية

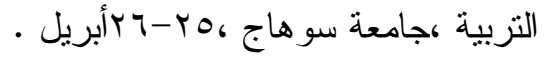

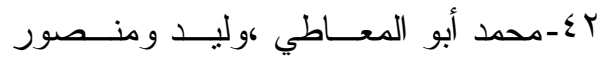

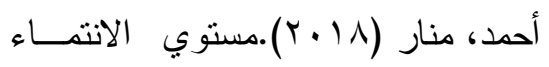

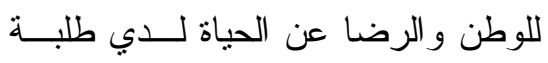

الجامعة (در اسة عبـــر ثقافيـــة مقارنــــة

)،مجلة البحث العلمي في التربية ، كلية

التربية ،جامعة المنصورة ،العدد (9 (1).

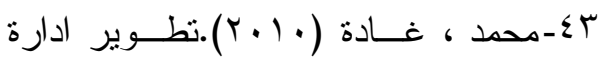

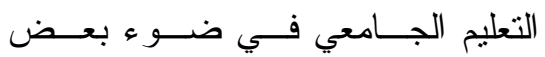

الاتجاهات الادارية الحديثــة ،رســـالة

ماجستير غير منششورة ،كلية التربيــة

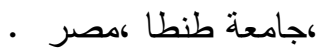

؟ §-مهناوي ،أحمد غنيمي ورمضان ،صلاح

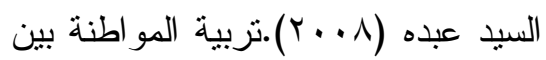

خصوصية الهويسـة وهيمنــة العولمـــة 


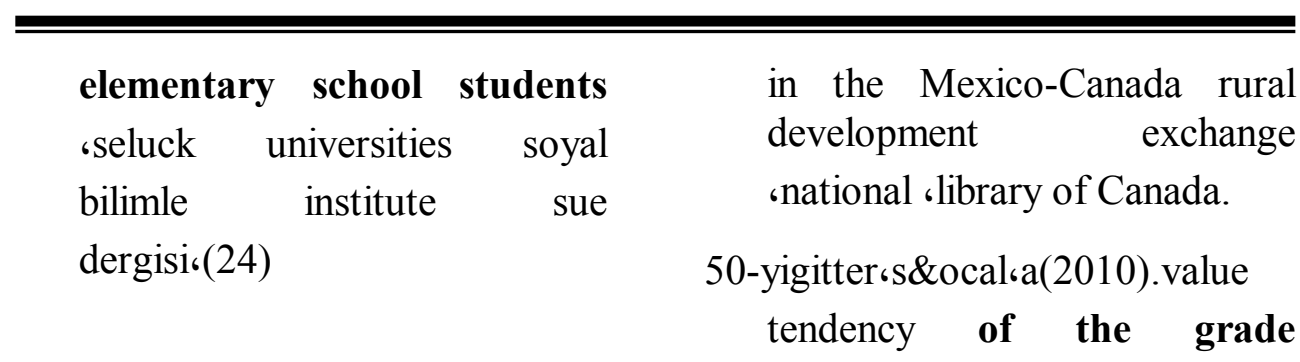

